\title{
Italo-Romance Metaphony and the Tuscan Diphthongs
}

\author{
Martin Maiden \\ Faculty of Linguistics, Philology, and Phonetics \\ University of Oxford \\ martin.maiden@mod-langs.ox.ac.uk
}

\begin{abstract}
The historical causes of general so-called 'opening' diphthongization of proto-Romance low mid vowels in stressed open syllables are an enduring matter of dispute in historical Romance phonology, the two principal positions being that the diphthongs originate in the assimilatory process of metaphony conditioned by following unstressed vowels, or that they are a matter of 'spontaneous' diphthongization associated with lengthening of the vowels. Most recent scholarship on the subject has tended to favour the latter view. This study, focusing on Tuscan (and thereby on Italian), reasserts the case for the former interpretation, critically reviewing older arguments and adducing new ones to show that the details of Tuscan open syllable diphtongization are significantly correlated with a metaphonic origin, despite claims to the contrary. In particular, I argue that the restriction of the generalized diphthongs to open syllables reflects the early conditions of metaphony, and that the occasional absence of the diphthongs in Tuscan systematically presupposes the historical absence of a metaphonizing environment. In conclusion, I reflect on the significance of my claims both for general Romance historical morphology and, particularly, for the place of Tuscan among the Italo-Romance dialects. The data also show how morphological analogy may play a significant role in the diffusion of the effects of sound change.
\end{abstract}

\section{INTRODUCTION}

Many Romance languages show the effects of historical diphthongization of the protoRomance stressed low mid vowels $*[\varepsilon]$ and $*[0]$ (derived in turn from Latin short $\breve{E}$ and O). ${ }^{1}$ For example, corresponding to proto-Romance *'tene 'hold.3sG.PRS', *te'neva 'hold.3SG.IPF' and *'more 'die.3SG.PRS', *mo'riva 'die.3SG.IPF', we have Italian tiene ['tje:ne] vs. teneva [te'ne:va] and muore ['mwo:re] vs moriva [mo'ri:va] or Castilian tiene ['tjene] vs. tenía [te'nia] and muere ['mwere] vs. moría [mo'ria]. The causes of such

\footnotetext{
${ }^{1}$ I wish to thank the editors of this journal, and two anonymous reviewers, for their extremely helpful and constructive comments on an earlier version of this study.
} 
diphthongization have long been controversial, and there are essentially two different views, both traceable to the late nineteenth century, and indeed to the same person, Hugo Schuchardt. ${ }^{2}$ These are, on the one hand, that the type of diphthongization illustrated above was an effect purely of stress or, on the other, that it was originally triggered by 'metaphony', an assimilatory raising of stressed vowels conditioned by posttonic high vowels ([i] and $[u])$, generally agreed also to produce diphthongs of this kind.

The controversy was already a venerable centenarian when I last engaged with it in the $1980 \mathrm{~s},{ }^{3}$ but it remains lively, and new interpretations and data continue to come to light. Whether there are, historically two separate kinds of diphthong, one metaphonic and one non-metaphonic, or whether they both originate in metaphony, is a question which bears on the historical unity of the Romance languages and in particular the historical unity of the Italo-Romance dialects. Moreover, if (as I shall contend) the origin is solely metaphonic, then this analysis will force us to recognize the significant role played by morphology, and specifically by paradigmatic inflexional information, in promoting the diffusion of the diphthongs beyond their originally metaphonic context.

Major contributions to the debate have come, over the past twenty years, in particular from Fernando Sánchez Miret and Michele Loporcaro. They, from somewhat different positions, both give an emphatic thumbs-down to the 'metaphonic' account.

\footnotetext{
${ }^{2}$ Cf. Purcinszky (1970:492f.).

${ }^{3}$ E.g., Maiden $(1986 ; 1987 ; 1988)$. It is fair to say that these attracted little detailed attention in the subsequent debate. An unhappy exception is Bargetto-Andrès (1998), who alas seriously misreads Maiden (1988), not least by attributing to me views which are unambiguously Schürr's. While bringing a large amount of new data and of new arguments to the debate, the present study also serves to re-present some of the ideas I developed in the 1980s.
} 
Sánchez Miret actually argues that the diphthongs are never possible outcomes of metaphony (even in those cases where they are conventionally acknowledged to be metaphonic), and have a quite different origin, in spontaneous diphthongization associated with vowel length. Loporcaro argues that the idea of a metaphonic origin for the diphthongs in Tuscan (and therefore in Italian) is a myth, and that they originate in an independent phenomenon of general Romance diphthongization in stressed open syllables. I shall not retrace the history of the debate and especially the protracted polemic between Friedrich Schürr and Arrigo Castellani (for a wide-ranging historical overview, see Sánchez Miret 1998; also Maiden 1988, and van der Veer 2006:15-22). My focus will be primarily on discussions over the last quarter-century.

2. ThE PROBlem OF THE RELATION BETWEEN STRESSED OPEN SYLLABLE DIPHTHONGIZATION VS METAPHONIC DIPHTHONGIZATION

The opening diphthongs arising from historically underlying $*[\varepsilon]$ and $*[0]$ mostly occur, within Italo-Romance, either in the form of stressed open syllable diphthongization, such that $*[\varepsilon]$ and $*[0]$ are diphthongized in all stressed open syllables, ${ }^{4}$ independently of any other phonological context, or in the form of metaphonic diphthongization, whereby posttonic unstressed ([i] and $[\mathrm{u}]$ ) produce an assimilatory effect, metaphony, ${ }^{5}$ on preceding stressed syllables, one output of which is diphthongization of low mid vowels. Note that metaphonic diphthongization is also assumed, conventionally, to be crucially

\footnotetext{
${ }^{4}$ By 'open' I understand a non-word-final syllable that does not end in a consonant. $/ \mathrm{Cr} /$ clusters also generally leave a preceding syllable 'open', but see Loporcaro (2011a:91f.).

${ }^{5}$ See for example Maiden (1991); Savoia and Maiden (1997).
} 
unlike stressed open syllable diphthongization by virtue of operating in closed and open syllables alike.

Stressed open syllable diphthongization characterizes most dialects of northern Italy and Tuscany (hence also Italian), together with parts of Umbria (e.g., Perugia, Gubbio); it also occurs in Oïl dialects (northern Gallo-Romance). Metaphonic diphthongization is best represented today in central and southern Italy, but it (or clear reflexes of it) recurs in Alpine Piedmontese and Lombard, and in Romagna. In most of Italy, metaphony affected both high and low mid stressed vowels $(*[\mathrm{e}], *[\mathrm{o}]$ and $*[\varepsilon], *[0])$, and more rarely also stressed *[a] (cf. Maiden 1987). High mid stressed vowels, *[e] and *[o], were invariably raised under metaphony to [i] and $[\mathrm{u}]$, while stressed $*[\mathrm{a}]$ generally yielded $[\varepsilon]$ (and sometimes $[j e])$, under metaphony. Low mid vowels $*[\varepsilon]$ and $*[0]$ likewise underwent raising by metaphony to [e] and [o] respectively, but their geographically most widespread outcome is diphthongization, in the form of opening diphthongs with an initial glide, usually [je] and [wo].

Table 1: Stressed open syllable diphthongization in Italian

\begin{tabular}{lll} 
open syllables & \multicolumn{2}{c}{ closed syllables } \\
*'pe.tra & $>$ pietra 'pje.tra 'stone' *'set.te & $>$ sette 'sct.te 'seven' \\
*'pe.de & $>$ piede 'pje.de 'foot' $\quad$ *'pel.le & $>$ pelle 'pel.le 'skin' \\
*'ro.ta & $>$ ruota 'rwo.ta 'wheel' *'mor.tu & $>$ morto 'mor.to 'dead' \\
*'no.vu & $>$ nuovo 'nwo.vo 'new' *'os.su & $>$ osso 'os.so 'bone'
\end{tabular}


Table 2: Metaphony and metaphonic diphthongization in central and southern ItaloRomance

Servigliano (Marche), with metaphonic raising of both high and low mid vowels (Camilli 1929)

$\begin{array}{llll} & \text { SG } & \text { PL } & \\ \text { M } & \text { 'spusu } & \text { 'spusi } & \text { 'spouse' } \\ \text { F } & \text { 'sposa } & \text { 'spose } & \\ \text { M } & \text { 'kwistu } & \text { 'kwisti } & \text { 'this' } \\ \text { F } & \text { 'kwesta } & \text { 'kweste } & \\ \text { M } & \text { 'mortu } & \text { 'morti } & \text { 'dead' } \\ \text { F } & \text { 'morta } & \text { 'morte } & \\ \text { M } & \text { a'pertu } & \text { a'perti } & \text { 'open' } \\ \text { F } & \text { a'perta } & \text { a'perte } & \end{array}$

Ischia (Bay of Naples), with metaphonic diphthongization of low mid vowels (and metaphonic raising of stressed high mid vowels and of stressed [a]). Data from Freund (1933):

SG

M 'surdə $(<*$ sordu $)$

F $\quad$ 'saurdə $(<*$ 'sorda $)$
PL

'surdə $(<*$ 'sordi $) \quad$ 'deaf'

'saurdə $(<*$ 'sorde) 


\begin{tabular}{|c|c|c|}
\hline $\mathrm{M} \quad$ 'issə $\left(<*^{\prime}\right.$ essu $)$ & 'issə (<*'essi) & 'he/they' \\
\hline 'Essə (<*'essa) & 'Essə (<*'esse) & 'she/they' \\
\hline 'vwostə (< *'vəstru) & 'vwostə (<*'vostri) & 'your’ \\
\hline 'vostə (<*'vostra) & 'vəstə (<*'vəstre) & \\
\hline pur'tjjeddə (<*por'kellu) & pur' tjeddə (<* por' kelli) & 'piglet' \\
\hline pur' tgeddə (<* por' kella) & pur' $\mathrm{f} \varepsilon \mathrm{dd} ə(<*$ por'kelle) & \\
\hline kajə'netə (<*kog'natu) & kajə'nctə (<*kog' nati) & 'brother-in-law' \\
\hline kajə' natə (<*kog'nata) & kajə'natə (<*kog'nate) & 'sister-in-law' \\
\hline
\end{tabular}

The problem is whether general stressed syllable diphthongization as found in Tuscan is historically related to metaphonic diphthongization, since their distribution appears quite different, the former occurring in stressed open syllables only, and apparently independently of the identity of the final vowel, while the latter occurs equally in open and closed stressed syllables and shows a strict historical dependency on the nature of the posttonic vowel. Maiden $(1987 ; 1988)$ argues that general stressed syllable diphthongization has its origins in metaphonic diphthongization, while Loporcaro (2011b:135) denies any link between them, and Sánchez Miret (1998), argues that even what is traditionally regarded as metaphonic diphthongization of low mid vowels is actually an impossible effect of metaphony.

Broadly, the 'non-metaphonic' accounts maintain that the diphthongs are the spontaneous result of vowel-lengthening under stress, given the greater length of vowels in stressed open syllables than in closed (e.g., Italian palla ['pal.la] 'ball' vs pala ['pa:.la] 'spade'; cf. Loporcaro 2011a:52). It is undoubtedly the case that lengthened vowels may 
diphthongize in stressed open syllables as a consequence of reduction in articulatory energy over their duration. The usual result, however, is a closing diphthong, whose effects are encountered in French and other northern Gallo-Romance dialects, Francoprovençal, Romansh, Friulian, the dialects of much of northern Italy, coastal areas of south-eastern Italy, and Vegliote. Most commonly affected are high vowels (but cf. Sánchez Miret 1998:217 or Loporcaro 2011b:138 for raising and fronting of [a] to [ $\varepsilon]$ in open syllables, possibly via a diphthongal stage), and especially [e] and [o]. Thus Bolognese and Vegliote:

Table 3: Diphthongization in stressed open syllables in Bolognese and Vegliote

\section{Bolognese}

\begin{tabular}{llll}
\hline *'tela & $>$ & 'taila 'canvas' & *a'more $>$ a'maur 'love' \\
\hline *'veskovu $>$ 'vafkuf 'bishop' & *'plombu $>$ pjæmp 'lead'
\end{tabular}

Vegliote

\begin{tabular}{lll}
\hline *'ripa & $>$ raipa 'bank' & *'krudu $>$ kroit 'raw' \\
\hline *'mille $>$ mel 'thousand' & *'bruttu $>$ brot 'ugly' \\
\hline *'pera $>$ paira 'pear' & *'kroke $>$ krauk'cross' \\
\hline *'peske $>$ pask 'fish' & *'monte $>$ muant 'mount'
\end{tabular}


It was precisely the characteristically 'closing' nature of Romance stressed open syllable diphthongizations that led Schürr (e.g., 1980:19-36;142-44) to deny that the opening diphthongs from $*[\varepsilon]$ and $*[0]$ could be the result of 'spontaneous' diphthongization of this kind. Sánchez Miret (1998:117), however, devises a scenario in which precisely this could have happened, even though it relies heavily on postulating hypothetical 'closing' protoforms $*[\varepsilon ə],{ }^{*}[0 ə]$, with subsequent modifications leading to opening diphthongs (Sánchez Miret 1998:117f.;135 cites parallels from northern Portuguese dialects). The fact remains that the opening diphthongs are unlikely (I do not say impossible) products of 'spontaneous' lengthening, and it remains to be established whether general stressed syllable diphthongization is genuinely incompatible with a metaphonic origin.

\section{DOES METAPHONIC DIPHTHONGIZATION EVEN EXIST?}

\subsection{Sánchez Miret's denial that metaphony produces diphthongs}

To even ask whether metaphonic diphthongization exists will surprise many Romance linguists, since it is generally accepted that [je] and [wo] are the regular outputs of metaphony of low mid vowels in many parts of Italy. Yet Sánchez Miret develops the unorthodox view that the opening diphthongs from low mid vowels are nowhere compatible with a metaphonic origin, even in those dialects where the diphthongs occur in historically metaphonizing contexts. This latter view means that a significant portion of what has traditionally been regarded as metaphony in Italy turns out not to be metaphony after all, and there could then be no question of the Tuscan diphthongs having a metaphonic origin. 
The basis of Sánchez Miret's claim is the difficulty of reconciling our understanding of the mechanics of metaphonic assimilation with the fact that while the onglide of the diphthong matches the conditioning vowels in position of articulation, the nucleus of the diphthong, intermediate between the glide and the assimilating high vowel, undergoes a lesser degree of raising (see also Purczinsky 1970:501) than the onglide. I think, however, that this reasoning (repeated in Russo and Sánchez Miret 2009:188f.) is open to challenge.

It certainly is puzzling that an assimilatory raising process should produce a diphthongal output whose onset appears to be fully assimilated for height to the vowel of the following syllable, but in which the nucleus fails to be equally raised, and it is unsurprising that the theoretical models of assimilation that Sánchez Miret surveys do not predict this outcome. ${ }^{6}$ But data should inform theory, not the reverse, and a safer conclusion from this apparently paradoxical situation is that we have an insufficiently fine-grained understanding of the early mechanisms of metaphony of low mid vowels, not that the diphthongs are not metaphonic. The circumstances of diphthongization of low mid vowels in much of central and southern Italy (and many parts of the north)

\footnotetext{
${ }^{6}$ I suggest that if the diphthong is an implausible output of metaphony of low mid vowels, then raising to [e] and [o] is at least equally implausible! These latter vowels are identical to the input to metaphony of high mid vowels, and there is a sense in which they contradict (or 'counterfeed') the assimilatory process, whose most natural implementation would be raising of all stressed vowels to the height of the conditioning vowels (cf. Maiden 1991:136-42;179-87). The diphthongs, in contrast, have the 'advantage' over [e] and [o] of being, at least in their onglide, fully assimilated to the height value of the final vowels!
} 
proclaim beyond reasonable doubt that the diphthong can be a result of metaphony. ${ }^{7}$ As we see in what follows, 'metaphonic' diphthongization is exactly like other forms of metaphony in terms of the phonological environment in which it occurs, and in terms of its output (all parts of the diphthong in fact originally involved raising, despite some apparent modern evidence to the contrary, which I address later); it usually co-exists with metaphonic raising of higher mid vowels and, sometimes, also with metaphonic raising of the lower vowel *[a]; the diphthongal outputs are also often found to be geographically adjacent to or intermingled with undisputedly metaphonic raising of $*[\varepsilon]$ and $*[\supset]$ to [e] and $[\mathrm{o}]$. All these facts favour the conventional view that diphthongization in metaphonic environments, and in metaphonizing dialects, is a regular output of metaphony.

Sánchez Miret believes, however, that the presence of the diphthongs before posttonic [i] and [u] is an effect not of metaphony but of an alleged lengthening of stressed vowels in the presence of closed unstressed vowels (the more open final unstressed vowels (namely [e], [o], and [a]), favouring shorter stressed vowels and thus resisting diphthongization). This is a claim of which I am sceptical for reasons to which I return later, but, even if we accept it for the time being, an obvious problem is that in most central and southern Italian dialects 'metaphonic diphthongization' occurs equally in open and closed syllables, but not in open syllables in non-metaphonic environments. If, as Sánchez Miret believes, the diphthongization is really a function of vowel duration,

\footnotetext{
${ }^{7}$ Barbato (2013:336) finds persuasive the idea that the diphthongs originate as a dissimilation (rather than an assimilation) of low mid vowels in metaphonizing environments, such that, for example, $\varepsilon>\varepsilon \varepsilon_{\uparrow}>$ e $\varepsilon>$ i $\varepsilon$, although he does not make it fully clear why this account (first advanced in print by Millardet 1910), is convincing, and he seems to assume that the nucleus of the diphthong originally remained a low mid vowel. We shall see later that the original metaphonic diphthongs most probably had a raised nucleus.
} 
and given that the vowels of stressed open syllables are systematically longer than those of stressed closed syllables, ${ }^{8}$ then the appearance of diphthongs in stressed closed syllables before [i] and [u] should lead us to expect their prior presence in all stressed open syllables, regardless of the identity of their following final vowel. This is simply not the case in central and southern Italy. Sánchez Miret acknowledges this difficulty, but his answer to it (1998:211) places an unbearable weight on morphological analogy. It is that, having become established in open syllables before unstressed [i] and [u] (where the stressed vowel is allegedly longest), the diphthongal alternants become 'morphologized' as exponents of the morphosyntactic categories associated with these desinences (mainly, plural and masculine singular in nouns and adjectives, second person singular in verbs), and are correspondingly transferred into closed syllables in those morphological environments. The analogical model of the morphological distribution of metaphony of high mid vowels is also invoked. It is claimed, in effect, that an alleged morphological analogy has the power to replicate, with uncanny accuracy, distributional effects which elsewhere are purely the result of regular sound change.

Sánchez Miret's claim seems to be motivated solely by the need to provide some explanation for the apparent anomaly just described. Yet it would be, prima facie, odd that a syllable structure allegedly refractory to the diphthongs should so eagerly host them merely under morphological pressure, and equally odd that such morphological pressure should nonetheless remain so exquisitely sensitive to the identity of the final

\footnotetext{
8 At any rate, this is clearly true for Italian in penultimate syllables, and is presumably true for much and possibly all of Italo-Romance. It is not necessarily true for antepenultimate syllables, which I discuss later. See, for example, D’Imperio and Rosenthall (1999:8;26) and Hajek and Stevens (2008:518f.).
} 
atonic vowels: we do not find SG 'dente PL 'denti 'tooth' becoming **'djente9 'djenti, for example, on the analogy of the type represented by masculine SG 'ljettu PL 'ljetti 'bed', even though both are masculine nouns, and this is obviously because the distribution of the diphthong remains strictly correlated with the presence of a final high vowel. Sánchez Miret (1998:209f.) cites divers examples from central Italian dialects in which morphological analogy does indeed lead to analogical creation of metaphonic alternation independently of the phonological environment (e.g., Sora MSG sən'norə 'gentleman' FSG *sən'nora 'lady' > sən' norə - sən' jəra), but such cases are, precisely, extremely sporadic. The incidence of diphthongization in closed syllables in central and southern Italy is of an utterly different kind: it is systematic and shows none of the sporadicity of occurrence, or insensitivity to phonological environment, that one would expect of a morphologically driven change.

The notion that the diphthongs are introduced into closed syllables on the analogy of patterns of morphological alternation associated with metaphony also predicts that non-alternating, morphologically invariant, words should not to diphthongize in closed syllables. Actually, morphologically invariant words containing stressed closed syllables do, or do not, show diphthongization in central and southern Italy as a strict function of the original identity of the final unstressed vowel. Compare the (morphologically invariant) Italo-Romance reflex of Lat. CĔNTUM 'hundred' with that of (accusative) UĚNTUM 'wind', as illustrated by AIS maps 304 and 399. Across central and southern Italy there is a virtually perfect match, such that diphthongization in one implies

\footnotetext{
${ }^{9}$ In what follows I use '**' to indicate forms whose existence is denied, and '*' for putative, but unattested, forms.
} 
diphthongization in the other, or metaphonic raising in one implies metaphonic raising in the other. ${ }^{10}$ Similarly, there is never in mainland central and southern Italy diphthongization in the reflex of the invariant numeral SĚPTEM 'seven', but there is in that of ŎСто 'eight' (AIS map 287) in those dialects (e.g., those of Calabria) where final etymological $*[\mathrm{o}]$ raised to $[\mathrm{u}]$ and regularly triggered metaphony/diphthongization (see, e.g., Maiden 1991:170). In short, the distribution of diphthongization in central and southern Italian closed syllables shows a characteristically phonological, 'metaphonic', sensitivity to the local historical identity of the final vowel, not to morphological (or lexical) categories. It is the result of sound change, and it cannot be accommodated with Sánchez Miret's idea that the diphthong is a result of lengthening in open syllables, analogically extended into closed syllables as well.

The relation between low mid vowel diphthongization and metaphony of stressed *[a] (see, e.g., Maiden 1987; 1991:115;131f.), reveals a further difficulty with Sánchez Miret's analysis. In eastern Abruzzo and in Molise, for example, diphthongization of low mid vowels is 'sandwiched' between metaphonic raising of high mid vowels *[e] and

\footnotetext{
${ }^{10}$ Trevi (pt 575) in Umbria has 'vjendu (with plural 'vendi!) vs 'tfendo, but note final [o] - a nonmetaphonizing environment. Similar forms are found in a few places in southern Marche and at Sant'Oreste (pt. 633) in Lazio, and perhaps also at Trasacco (pt. 646), where the original identity of the final vowel is unrecoverable. At Morrone del Sannio (pt. 668) and Picerno (pt 732) there is also a mismatch, but here it is 'wind' that lacks the diphthong, not 'hundred'. In an otherwise excellent exploration of metaphonic diphthongs in Verbicaro (Calabria), Silvestri (2009:179f.) curiously asserts that 'in general' southern Italian reflexes of CĔNTUM lack a metaphonic vowel. This is contradicted by AIS map 304 which she cites, and by the even more detailed coverage of the $A L I$ responses (unpublished, question 38) for this word, except for some points in the eastern and southern extremities of Salento.
} 
$*[0]$ and metaphony of $*[a]$. This is unremarkable if we accept that the diphthongs, too, reflect metaphony, but it is a serious problem for Sánchez Miret, since his account of diphthongization requires that $*[\varepsilon]$ and $*[0]$ never underwent metaphony (if they had, there would be no input to diphthongization, since the low mid vowels would have been metaphonically raised to [e] and [o]). It is implausible that metaphony could have operated both on high mid vowels and on *[a] while 'leap-frogging' the intermediate low mid vowels. One possible solution to this objection might be to say that when diphthongization occurred, metaphony only operated on high mid vowels, but not yet on lower vowels (see Maiden 1987). The diphthongization and the alleged analogical extension of the diphthongs into closed syllables might then have occurred, in ItaloRomance, after metaphony affected high mid vowels but before it reached *[a]. Such a scenario would involve a peculiar claim, however: not only diphthongization but also a massive and exceptionless series of analogical adjustments have apparently managed to insinuate themselves perfectly between the chronological beginning of metaphony (when it allegedly acted just on high mid vowels) and its end (when it came to act on *[a]), both in phonological space and in time. It stretches credulity far less to accept that the ItaloRomance dialects that have metaphony of high mid vowels and of *[a] always also have metaphony of low mid vowels and that, in a great many places, the latter's output happens to be a diphthong.

3.2 Diphthongization and metaphonic raising as complementary facets of the same phenomenon? 
The notion that [je] and [wo] are not plausible direct outputs of the metaphony of low mid vowels also runs foul of the fact that the diphthong and the raised vowel sometimes appear to be just complementary facets of metaphony (cf. Franceschi 1979:1921; Schürr 1970b:24f.). Indeed, the distribution of metaphonic raising of low mid vowels and diphthongization of low mid vowels, both geographically and sometimes within one and the same variety, creates a powerful impression of complementarity which, in turn, suggests historically underlying unity. Raising is characteristic of a band of dialects between Rome and Ancona flanked to the north and south by diphthongizing dialects. It reappears in parts of western Abruzzo (Giammarco 1979:30), in sporadic outcrops in northern Puglia (surrounded by diphthongization, see Stehl 1980 maps 9 and 14) and in southern Lazio and northern Campania (e.g., Sora) and some localities of the Calabrian province of Cosenza (Cellara, Malito, Belsito, see Falcone 1976:12). In every case, the linguistic atlases reveal that dialects with monophthongal output are interspersed among others having diphthongization. The same effect is observable for reflexes of $*[\varepsilon]$ in some Alpine dialects (e.g., Sonogno, Mesolcina, Leventina); again, immediately neighbouring dialects display clearly diphthongal reflexes.

We can at least be clear that metaphony produces both a diphthong and a raised vowel, and the balance of evidence points in the direction of the latter being a secondary phase of the former - a view held, for example, by Schürr (1970b:24f.). Others, such as Loporcaro (2011b:132f.), ${ }^{11}$ argue for the reverse. Loporcaro observes, for example, that in the dialect of Agnone (Molise) some vowels are subject to spontaneous diphthongization in 'prepausal' position (cf. also Loporcaro 2011a:76f.), but not

\footnotetext{
${ }^{11}$ See also Merlo (1920:232), Weinrich (1958:41f.), Leonard (1978:55n27).
} 
elsewhere, e.g., diphthongization of stressed [i] to [oj] in prepausal 'Jta mm a ssən'dojə 'stand and listen to me' but not in non-prepausal ' $\mathrm{fta} \mathrm{mm}$ a ssən'di 'vuonə 'stand and listen to me well'. Now, both a raised vowel and a diphthong also appear in Agnone as reflexes of metaphony of low mid vowels, but this diphthong, too, only appears prepausally (e.g., nna to 'sizndə 'how do you feel?'), the raised vowel occurring in other positions (e.g., n də 'sendə 'vuonə 'you don't feel well'). Loporcaro concludes that 'this can only mean that metaphony first caused raising of proto-Romance $[\varepsilon]$ (as well as [o]) to [e] (and [o]), which subsequently diphthongized'. To me it seems to show that both are possible outcomes of metaphony, and that they might have been subsequently redistributed according to a principle such that diphthongal variants are, indeed, preferred in prepausal position. Actually, given certain evidence (cf. Rohlfs 1938:54f. for metaphony of *[a] in Pozzuoli: *'manu > (a) 'menə '(the) hand' but a 'manə ma' latə 'the injured hand') that metaphony itself may have originally favoured syllables bearing phrasal stress, the Agnonese data might indicate that the diphthong is the earlier form of metaphony of low mid vowels, and that it was subject to monophthongization outside prepausal position.

An additional piece of evidence which Loporcaro (2011b:695) adduces in favour of his position strikes me as pointing in the opposite direction. This concerns the suffix which in modern Italian has the form -iere or -iero (feminine -iera) and which is generally acknowledged to have been introduced into Italo-Romance as a loan from Gallo-Romance (cf. Rohlfs 1969:431f.; Cella 2003:60;258-63). In Agnonese, the word for 'barber' (cf. Italian barbiere) is var' viərə under phrasal stress, but var' verə elsewhere; since we know the diphthong in this case to be historically underlying, what we actually 
have here is proof that the diphthong can become [e], not of the reverse. Indeed, the behaviour of this suffix elsewhere in central and southern Italo-Romance provides further evidence for the change [je] $>$ [e]. It frequently surfaces with the closed mid vowel [e], and indeed in some localities (as in Agnone) it shows exactly the same vowel as the output of metaphony of $[\varepsilon]$. Compare, for example, AIS map 163 piedi 'feet', with map 978 saliera 'salt cellar' for Sant'Elpidio a Mare (pt 559), Tagliacozzo (pt 645), Serrone (pt 654), Sonnino (pt 682), Colle Sannita (pt 714), and also map 244 for reflexes of -iere in the word for 'butcher'. See also Carosella (2005:94;99;App.2_esiti_di_e) for the treatment of this suffix in the dialects of Gargano, Medori (2013:133) for Corsica, and LEI for barbiere 'barber', s.v. BARBA.

More evidence for a change [je], [wo] > [e], [o] comes from Corsica. Here there is (cf. Dalbera-Stefanaggi 1991:541; Barbato 2006:9;14) an inversion of historically underlying openness values $(*[\varepsilon], *[0]>[\mathrm{e}],[\mathrm{o}] ; *[\mathrm{e}], *[\mathrm{o}]>[\varepsilon],[\mathrm{o}])$, such that original high mid vowels emerge as low mid vowels, while original low mid vowels emerge as high mid vowels. Such an inversion can only have been possible if, at the time when the high mid vowels were being lowered, the continuants of the low mid vowels had some form other than their modern outcomes [e] and [o] (otherwise, we could not explain why these, too, were not lowered). A likely candidate for this other phonological content, since it is independently attested as a reflex of low mid vowels, is a diphthong, which later monophthongized (cf. Barbato 2006:14). ${ }^{12}$ To conclude, the diphthongal output of

\footnotetext{
${ }^{12}$ Loporcaro (1988a:68-73; 2011b:118n18) describes similar phenomena, in the area around Bari, which are inexplicable in terms of diphthongization, and where an explanation in terms of an intermediate centralizing 'disturbance' of the high mid vowels, for which there is abundant independent evidence, seem
} 
metaphony of low mid vowels seems to be organically connected with the raised and unambiguously metaphonic output: there is no incompatibility between them.

\subsection{Are Tuscan [je] and [wo] impossible outputs of metaphony?}

Finally, a different kind of objection (see, e.g., Loporcaro 2011b:133) to the claim that the Tuscan diphthongs have a metaphonic origin is that they deviate from the metaphonic diphthongs found elsewhere in Italy in containing an open, rather than closed, mid vowel: [je], [wo], not [je], [wo]. Given that metaphony is an assimilatory raising, how could the output contain a diphthong whose nucleus remains no higher than the input? This would be a problem if there were not evidence that the Tuscan diphthongs were also, originally, *[je], *[wo], their nuclei having been later subject to lowering. This evidence comes from front vowels, although it is reasonable to assume a parallel development for back vowels. In fact, stressed [je] barely seems to exist in modern Tuscan, ${ }^{13}$ even where it would be

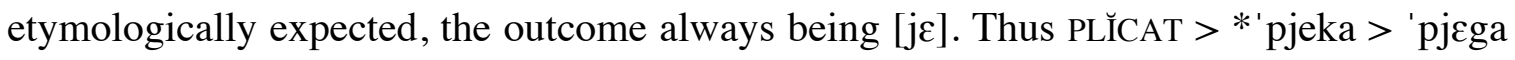
'folds'; PLĒNUM > *'pjeno > 'pjeno 'full'; PLĒBEM > *'pjeve > 'pjeve 'parish'; FLĒBILEM

plausible. Such inversion (affecting the front vowels) in eastern Catalan probably has a similar explanation (Badía Margarit 1951:138;141; Moll 1952:72f.; Sánchez Miret 1998:235f. n99). There is no evidence that such an explanation is available for Corsica, however.

${ }^{13}$ An exception is Pomonte (Elba, AIS pt 570), where the diphthong is frequently [je], probably preserving its original form: e.g., 'pjedi 'foot', 'fjera 'fair', 'tjeni 'you hold', 'ceko $\left(<*^{*}\right.$ 'fjeko) 'blind', 'serjo (< *'sjero) 'whey' (but also 'vjeni 'you come', 'fjele 'bile', 'djetro 'behind'). The outcome of the original diphthong of the back low vowel is often [o], suggesting an earlier stage $*$ [wo]: e.g., 'kore $(<*$ 'kwore) 'heart', 'foko (<*'fwoko) 'fire', 'kofe (<*'kwotfe 'cooks'). The diphthong [je] also frequently occurs at Stazzema in the province of Lucca: cf. ALEIC maps 157, 923, 1578, 1885, 1940, for point 55. 
$>$ *'fjevole $>$ 'fjevole 'feeble'; BĒTULAM $>*^{*}$ bletola $^{14}>*$ 'bjetola $>$ 'bjetola 'beetroot', etc. This development of $*[\mathrm{je}]$ is sometimes attributed to an alleged analogical 'attraction' exercised by the diphthong $[j \varepsilon]$, the assumed regular output of $*[\varepsilon]$ (e.g., D'Achille 2001:47), but this claim is implausible in a region of Italy which otherwise maintains a robust distinction between open and closed values for mid vowels. One would, at least, expect to see some occasional remnants in Tuscan dialects of original *[je], if the change were a matter of some kind of 'analogy', but what one actually sees (e.g., AIS maps $131 ; 1335 ; 1362 ; 1530)$ is very consistently ${ }^{15}[\mathrm{j} \varepsilon]$. In reality, it seems perfectly likely that an original $*[j \mathrm{je}$ (identical to the diphthongizing outcome of metaphony found elsewhere in Italy ${ }^{16}$ has become $[\mathrm{j} \varepsilon]$, perhaps by a process of dissimilation, and one may assume a parallel development for the back diphthong.

To conclude, [je] and [wo] (and their Tuscan variants [je] and [wo]) are fully compatible with a metaphonic origin. Indeed there is evidence that [je] and [wo] may, in general, have been the earliest metaphonic output of low mid vowels. The fact remains, however, that the Tuscan diphthongs (apparently unlike metaphony) do not occur in

\footnotetext{
${ }^{14}$ See also AIS map 1362. The origin of the first /l/ is problematic (see, e.g., Rohlfs 1966:456, LEI s.v. BETA, 2.), but that it is historically underlying is not in doubt.

${ }^{15}$ There is 'pjega in eastern Tuscany (e.g., Cortona), but we cannot rule out analogical influence exercised by forms of this verb where stress does not fall on the root, closure of unstressed $[\varepsilon]$ to [e] being phonetically normal in those forms.

${ }^{16}$ Curiously, Russo and Sánchez Miret (2009:190) assume that [je] and [wo] are generally the historically underlying forms, but I see no evidence in the rest of Italy, where [je] and [wo] predominate. And crucially this means that what is involved really is a matter of anticipatory raising, affecting not only the onglide but also the nucleus, before a high vowel.
} 
closed syllables, ${ }^{17}$ and that their distribution is (apparently) not correlated with an originally metaphonizing environment. I shall show in sections 4 and 5 that these discrepancies are indeed only 'apparent'

\section{OLD ARETINE DIPHTHONGIZATION, SYLLABLE STRUCTURE, AND METAPHONY}

4.1 Historical restriction of metaphonic diphthongization to open syllables in Arezzo and area

Arezzo lies in eastern Tuscany, close to the border with Umbria and on the periphery of the Tuscan area showing general stressed open syllable diphthongization of low mid vowels. Medieval Aretine occupies a particularly significant and controversial place in the debate about the origin of the Tuscan diphthongs. It had diphthongization of the low mid vowels limited to open syllables, like modern Tuscan; unlike modern Tuscan, metaphonic diphthongization in open syllables was, with very few exceptions, limited to historically metaphonizing environments: i.e., it appeared only before -[i] and (historically underlying) $*_{-}[\mathrm{u}]$ (the latter subsequently becoming -[o] in Tuscan).

Table 4: Distribution of low mid vowel diphthongization in old Aretine

\begin{tabular}{|c|c|}
\hline sola 'sole' < *'sola & -uolo -uoli (suffix) < *_'slu *_'olu \\
\hline bona 'good.F'<*'bona & buono 'good.M' < *'bonu \\
\hline nova 'new.F' < *'nova & nuovo 'new.M' < *'novu \\
\hline
\end{tabular}

\footnotetext{
${ }^{17}$ Exceptions have clear and specific motivations, such as analogical levelling in the verb chiedere 'ask', yielding past participle chiesto.
} 
omo 'man' <*'omo

grosso 'big.MSG' < *'grossu grossi 'big.MPL' < *' grossi

$\begin{array}{ll}\text { dede 's/he gave' <*'dede } & \text { diedi 'I gave' <*'dedi } \\ \text { vene 's/he comes' <*'vene } & \text { vieni 'you come' <*'veni }\end{array}$

bello 'beautiful.MSG' <*'bellu belli 'beautiful.MPL' <*'belli

pè 'foot' <*'pede piei 'feet' < *'pedi

In Restoro d'Arezzo's Composizione del mondo colle sue cascioni (1282), of 540 instances of $u o,{ }^{18}$ none occurs in closed syllables and only five in historically nonmetaphonizing environments. These latter are the verb-forms muove 'moves' (two instances vs. 56 move) and vuole 'wants' (two instances vs. 25 vole), and the noun cuore 'heart' (one instance vs. 11 core). Of over 800 examples of $i e$ from proto-Romance $*[\varepsilon],{ }^{19}$ all fall in historically metaphonizing environments and in open syllables, except for two examples of feminine cieca 'blind' (but this could just be a graphy for *'tycka), one of feminine plural entiere 'whole' (although see section 3 on forms in -iero, -iere, etc.), one of tiene 's/he holds' (vs. 21 of tene) but also, curiously, 12 of derietro 'behind' (vs. 62 of (en)deretro), from DE RETRO, and 79 examples of asieme/ensieme/insieme 'together' (vs. just one of enseme). Note that whatever the origin of the diphthong in

\footnotetext{
${ }^{18}$ Data from $O V I$. I exclude from consideration instances of the feminine suffix -uosa, -uose, which is a phonologically learnèd form (< Lat. -UOSA, etc.).

${ }^{19}$ I exclude over three hundred examples of the (largely) agentive suffix -ieri (both plural and singular). This happens to conform perfectly to the principle that the diphthong should occur in a historically metaphonizing environment, but the suffix (a variant of -iero, -iere) is almost certainly a loan form (see section 3).
} 
asieme/ensieme/insieme, its cognate forms also show a diphthong over vast areas of central and southern Italy where the diphthong is otherwise only found as a consequence of metaphony (cf. AIS map 1635), ${ }^{20}$ so that the behaviour of old Aretine in this respect turns out to be fully consonant with that of undisputedly metaphonizing dialects. The same cannot be said of derietro, but it is a minority form beside deretro.

Other dialects of adjacent areas of medieval Tuscany and Umbria tend to show similar distribution of the diphthong, although the correlation with a metaphonic environment tends to be better preserved for back vowels. Thus the $O V I$ data from Sansepolcro show an asymmetrical distribution, such that $u o$ occurs almost exclusively in historically metaphonizing contexts (only one of 32 examples, namely figliuola 'daughter', does not), whereas for ie only four out of 16 examples are in metaphonizing environments. Texts from Città di Castello $(O V I)$ have well over 800 instances of $u o$, almost always in originally metaphonic contexts. Exceptions showing the diphthong in non-metaphonic environments are isolated, and heavily outnumbered by examples of the same word lacking the diphthong (e.g., one buona 'good' vs. 21 bona, one buove 'ox' vs. 35 bove, one uom 'man' vs. 48 om(o), one fuore 'out' vs. 29 fore). For ie the position is more complex, but the historical environment is overwhelmingly metaphonic (except for the type ensieme 'together' and derietro 'behind', for which see above); other cases such as tiene or viene 'he holds/comes', priego, priega 'I/he pray(s)', are vastly outnumbered

\footnotetext{
${ }^{20}$ Interestingly, both inseme and retro exceptionally appear without a diphthong in old Lucchese, a fact which Castellani (1980a:128f.) is forced, ad hoc, to attribute to an otherwise unexplained pronunciation of the $e$ as [e]. But they are exactly cases of historically non-metaphonizing environments. Gibellini (1991:746) notes dereto and areto among words exceptionally lacking diphthongization in the nineteenth century Roman dialect writings of Giuseppe Gioachino Belli.
} 
by the expected non-diphthongal tene, vene, prego, prega. The nineteenth century dialect of Città di Castello (Bianchi 1886; Castellani, 1980h:489f.) shows [je] generalized to all stressed open syllables; however, [wo], also found only in open syllables, still occurs exclusively in originally metaphonic environments: 'nwovo 'new' < *'nэvu, 'bwoni 'good', 'fwoko 'fire' < *'f foku, 'fora 'outside', 'kore 'heart', 'omo 'man' < *'omo. Mancarella (1964:27f.) notes for fourteenth-century Gubbio a situation where diphthongs are still predominantly associated with the original metaphonic environment. ${ }^{21}$ On the other side of Tuscany (Castelnuovo di Garfagnana, in the far north-west), Giannini (1939) describes a situation where non-metaphonic environments still remain the locus of non-diphthongization of [0] in open syllables. ${ }^{22}$

\subsection{Traditional interpretations of the old Aretine data}

The old Aretine facts have a central, but controversial, position in the debate about the origin of the Tuscan diphthongs. A helpfully succinct description of how they have been interpreted is given by Loporcaro (2011b:121f.):

\footnotetext{
${ }^{21}$ It must be noted that in Gubbio there are also a substantial minority of cases in which the diphthong is absent from the metaphonic environment. This perhaps reflects speakers' uncertainty, in the face of the innovation, as to which syllables do, or do not, take the diphthong. See also Sestito (2004:167) for medieval Assisi (Umbria).

${ }^{22}$ This much can be said for Giannini's data. For a justifiably sceptical review of Schürr's much stronger claim that they show the same 'intermediate phase' in the re-arrangement of the diphthongs as he discerns in medieval Aretine, see Castellani (1980e:163-65;172f.).
} 
The occurrence of the [old Aretine] type has been taken as proof that all $\breve{\mathrm{E}}$ and $\breve{\mathrm{o}}$ diphthongization, even that of Florentine, was originally metaphonic in nature (e.g., Schürr 1965; 1970[b]:32-[41]; 1972). On this view, the Florentine distribution buono, $-a$, $-i$, $-e$ vs. grosso, $-i,-a,-e$ was created via superimposing (an originally metaphonic) diphthongization, coming from either northern or central southern dialects, onto a reconstructed proto-Florentine variety which had by hypothesis no diphthongs at all. When metaphonic diphthongization was imported, then, it became sensitive, only in Tuscany, to syllable structure and analogical levelling took place with /wo/ (and /je/) generalized to whole paradigms provided that the (purportedly new) syllabic constraint [...] was met, and eliminated, on the other hand, from all checked syllables. On this view the OAretine pattern [...] is a remnant of a transitional stage, still attesting to the first introduction of diphthongization (still subject, by hypothesis, to metaphonic conditioning) into Tuscany. In the same vein, lack of diphthongization in Florentine (and Standard Italian) bene 'well' (adverb), nove 'nine' has been interpreted as a relic of the original situation, left untouched by analogy since these morphologically invariant words were not part of any paradigm and consequently there was no allomorph from which the diphthong could spread.

Friedrich Schürr viewed the old Aretine data as representing a transitional stage in the passage from what was originally metaphonic diphthongization to the situation found in Tuscan. For Schürr's major antagonist in this debate, Arrigo Castellani, these data were, however, unconnected with Tuscan generalized stressed open syllable diphthongization (Arezzo being in his opinion peripheral and subject to linguistic influences from outside Tuscany). In my view, both scholars $^{23}$ overlooked the true significance of these data: if metaphony in old Aretine is restricted to open syllables, and

\footnotetext{
${ }^{23}$ Russo and Sánchez Miret (2009:188) also dismiss any possibility that old Aretine could constitute a 'starting point' for generalized diphthongization.
} 
there is no evidence at all for metaphony in closed syllables, the most reasonable assumption is that this is because metaphony originally only applied in open syllables, and that Arezzo preserved that early state of affairs (for an extended argument that absence of metaphony anywhere in Italy should be interpreted as historically underlying in the absence of any compelling explanation of its 'removal', see particularly Maiden 1987). If we assume this much, then one major source of apparent incompatibility between Tuscan stressed open syllable diphthongization and metaphonic diphthongization could simply dissolve, for both can be taken to originate in open syllables.

Castellani, in his fervour to defend the view that the Tuscan diphthongs are autonomously Tuscan, pays remarkably little attention to the phonological details of the Aretine phenomena and especially to the absence of the diphthong from closed syllables. His efforts, rather, are devoted to asserting that these facts are somehow external to Tuscan, and therefore irrelevant to the question of the origins of the Tuscan diphthongs (see, e.g., Castellani 1980b:144;166). But what is in fact irrelevant is whether old Aretine counts as 'Tuscan' or not: what matters, rather, is that there existed, in central Italy, dialects in which metaphonic diphthongs were restricted to open syllables, and that this occurred in territory adjacent to - not to mention otherwise phonologically very similar to - the area of stressed open syllable diphthongization. Castellani (1980c:415) simply $\operatorname{asserts}^{24}$ that the Aretine type comes from outside Tuscany and that 'conditions favourable to the development of a diphthongization in open syllables conditioned by final vowels certainly obtained in the northern Marche, where metaphonic influences

\footnotetext{
${ }^{24}$ See also Serianni (1972:66), Russo and Sánchez Miret (2009:188).
} 
from Romagna and from territories beyond the river Esino ${ }^{25}$ overlapped' [my translation]. What exactly these 'conditions' might have been, and what mechanism could have determined the emergence of the Aretine pattern, is never explained (cf. also Schürr 1972:320). Yet it was precisely the mechanism of this metaphonic diphthongization, and also that of Tuscan stressed open syllable diphthongization, that Castellani needed to address.

Friedrich Schürr believed that the pattern of diphthongization found in Tuscan was the effect of a principle of 'syllabic isochrony', which he believed to have spread into Italy from central Gaul, and which (he claimed) had involved reinterpretation of metaphonic diphthongs as 'long' counterparts of the low mid vowels, whence their generalization in all stressed open syllables (characterized by long vowels), and their expulsion from closed syllables (characterized by short vowels followed by a consonant). In reality, Schürr never made it clear what it was about the diphthongs that would have inclined speakers to regard them as 'long' equivalents of the monophthongs, beyond saying that lengthened vowels and the onset of the diphthongs have a common characteristic in 'tenseness' (Schürr 1970b:81). If the diphthongs were equivalent to a long vowel, one would expect to find in Tuscan **['mjele] and not the actually occurring ['mje:le] 'honey'. In fact, as this example shows, lengthening in stressed open syllables seems independent of diphthongization.

In any case, a central flaw in Schürr's analysis is that he insists (e.g., Schürr 1970a:397; 1972:317f.) on viewing old Aretine as a 'transitional' or 'intermediate' stage in this passage from metaphonic diphthongization to stressed open syllable

\footnotetext{
${ }^{25}$ I.e., of the central Italian type.
} 
diphthongization. For most of his career he accepted two pieces of received wisdom about metaphony: that it was not native to Tuscany, and that it had always operated in open and closed syllables alike. Ultimately he came close to abandoning the first of these. After having believed at different times that the metaphonic diphthongs entered Tuscany from the south, or from the north, he also allowed (1972:320f.) that metaphonic diphthongization might have been indigenous in Tuscany. He continued, however, to assume that metaphony had operated regardless of syllable structure, and this in turn required from him an account of the phonological details of the 'transitional' phase and particularly of the assumed expulsion of the diphthongs from closed syllables. The trouble with the account he gives is that it is fundamentally implausible, and incompatible with the facts. Interestingly, certain of the difficulties which attend Schürr's analysis actually apply also to Loporcaro's rebuttal of that analysis, which I present here (Loporcaro 2011b:122f.):

The OAretine pattern lends itself equally to an interpretation diametrically opposed to Schürr's. If one assumes that open syllable diphthongization and metaphony arose as two distinct processes (as argued e.g. by Wartburg 1950:122f., Lüdtke 1956:82f.), in different areas - the former in central Tuscany, the latter both north and south-east of Tuscany - then OAretine, lumping together the two conditions, can be conceived as a compromise between the two, which fits well with the geolinguistic position of the dialect. On the contrary, if only metaphonic diphthongization had arisen initially, then one would have to assume (as Schürr does) that OAretine is more conservative than Florentine and that the open syllable restriction first arose in south-eastern Tuscany, to then spread gradually westwards so as to conquer Florence as well. This assumption is however at odds with what is independently known about the socio-geolinguistic situation of central Italy.

$[\ldots]$ 
All in all, the evidence seems to militate in favour of Castellani's (1970[:37]5) conclusion: '[c]learly, in Arezzo there is no preservation of a mythical palaeo-Tuscan stage. One simply finds a different type of development.

Now, in fact, what we see in old Aretine not only looks absolutely nothing like a 'compromise', ${ }^{26}$ but also looks nothing like what one would expect to happen in the face of an incoming innovatory system of 'syllabic isochrony'. One must insist here on the 'neatness' of the distributional contours of diphthongization in Arezzo: absolutely no diphthongs in closed syllables, and diphthongs well-nigh exclusively limited to (formerly) metaphonizing environments in open syllables. On either Schürr's or Loporcaro's account, an indigenous and familiar pattern of metaphonic diphthongization is allegedly partially abandoned in the face of a phonological innovation from outside. In such circumstances one would expect to see something far more 'messy' than what we observe: lexically sporadic retention of the 'native' diphthong in closed syllables and equally sporadic spread of the 'non-native' diphthong outside the metaphonic environment in open syllables. One really does encounter situations of this kind in other parts of central Italy (cf., e.g., Reinhard 1956:11 for Orvieto), where the two patterns have 'overlapped' historically, but in Arezzo there appears to have been not so much a 'compromise' as abject 'surrender' in closed syllables, yet heroic and unyielding 'resistance' in open syllables. Why? Would speakers really behave in this kind of rigidly differentiated way in the face of an innovation? Schürr claims that 'syllabic isochrony'

\footnotetext{
${ }^{26}$ I do not see, by the way, that Schürr's account in any way requires one to suppose that the open syllable diphthongization 'spread westwards' from south-eastern Tuscany. The claim is merely that old Aretine represents an early stage in a development which has proceeded far further elsewhere.
} 
led to reinterpretation of metaphonic diphthongs as 'long' counterparts of the low mid vowels, and the consequent expulsion of the diphthongs from closed syllables and their generalization in open syllables. The problem is that a principle predicted to act on open and closed syllables alike seems actually to have acted only on the latter, whilst leaving the former curiously untroubled. Schürr $(1970 \mathrm{~b}: 155 ; 1980: 59)$ says that the diphthongs had been evicted from closed syllables because they had become 'intolerable' there, but the only evidence that the closed syllable diphthongs were 'intolerable' is the very thing that needs explaining, namely the fact that there are no diphthongs in closed syllables. And it is hard to see how a native and previously perfectly 'tolerable' phenomenon could be transformed into something completely 'intolerable', allegedly due to external agency.

\subsection{Old Aretine preserves an early stage of metaphony, restricted to open syllables}

Old Aretine should be taken at face value: it is simply an example of a central ItaloRomance dialect in which metaphony of low mid vowels never occurred in closed syllables. It may indeed be regarded as significantly 'transitional' from a geographical point of view, since it lies between Tuscan dialects with generalized open syllable diphthongization and central and southern dialects having metaphony in closed as well as open syllables - but there is no reason to think it diachronically 'transitional'. Rather, it can perfectly well be a remnant of a primordial stage from which both the Tuscan type of diphthongization and metaphonic diphthongization in closed syllables emerged. Indeed, it may be interpreted as geographically 'peripheral' rather than 'transitional', possibly lying at the south-eastern edge of what may once have been a vast area in which metaphony had remained confined to open syllables. 
4.4 Further evidence that metaphony was originally sensitive to syllable structure

The notion that metaphony was sensitive to syllable structure is independently supported. Most of the evidence comes, in fact, from metaphony of low mid vowels, and is found today in dialects of northern Puglia and particularly the Gargano peninsula. In Torremaggiore and Lesina (De Angelis 1921:49; Melillo 1955: pt 7; Stehl 1980:58;97; Maiden 1988:20f.) metaphony of [o] is frequently absent from closed syllables. The $A L I$ data for reflexes of *kap'pellu 'hat' and *'lektu 'bed' (questions 608 and 1063) also show metaphony to be absent for front vowels in closed syllables in Torremaggiore. Carosella (1997:156-58) further confirms the tendency for metaphony of low mid vowels to be absent in closed syllables in Gargano dialects, notably in San Paolo Civitate and to some extent in Poggio Imperiale and Apricena. Serracapriola lacks metaphony of low mid vowels before original $[u]$ in closed syllables ${ }^{27}$ Carosella (1999:123n84) attributes this fact to the shorter duration of vowels in closed syllables ${ }^{28}$ Closer to Tuscany, we also find dialects in Lazio (see Vignoli 1925:11f.;14f. for Veroli; Maccarrone 1915 for Cassino; Maiden 1988:21) where metaphony of low mid vowels by [u] tends to be blocked, but always in closed rather than open syllables. This may also be the case (but see Reinhard 1956:17) in the Umbrian dialect of Amelia. In Puglia (cf. Melillo 1926 and Carosella 1999:120n71 for Sannicandro Garganico; Stehl 1980:37 for Corato; Maiden 1988:20)

\footnotetext{
${ }^{27}$ As argued in Maiden (1987), this kind of fact probably means that by the time metaphony penetrated closed syllables, final $[\mathrm{u}]$ had opened to [o] and therefore could not trigger metaphony.

${ }^{28}$ She also sometimes appeals $(1997: 156 n 59 ; 1999: 128)$ to 'Italian' influence to explain the absence of metaphony. In words such as 'eye', and many others from basic vocabulary, this seems implausible.
} 
there are also some signs of resistance to metaphony of high mid vowels in closed syllables.

Yet more evidence for the sensitivity of metaphony to syllable structure involves metaphony of *[a], the result of which is usually a mid front vowel (generally $[\varepsilon]$ ). In some dialects of western Abruzzo and of Molise this output appears, however, to have 'fed' metaphony of $*[\varepsilon]$, so that both input vowels show identical metaphonic outputs. Thus Castelli (province of Teramo; AIS pt 618): *'pedi 'feet' > pi:t, *'api 'bees' > i:p; *aw'kelli 'birds' > tyiel, *'blanki 'white'MPL > bliegk. However, in some dialects of Molise there is asymmetry according to syllable structure, with metaphony of $*[a]$ in open syllables producing a diphthongal output identical to that of metaphony of $*[\varepsilon]$, whilst in closed syllables (and proparoxytones) the result of metaphony of *[a] advances no further than $[\varepsilon]$. Metaphony of $*[\varepsilon]$ in these dialects never differentiates syllable structure. This is what happens, for example, in the dialect of Agnone, as described by Ziccardi (1910:407f.): ${ }^{29}$

Table 5: Metaphony of $[\varepsilon]$ and [a] in Agnone

\begin{tabular}{|c|c|c|c|c|c|}
\hline *'kani & $>\quad$ 'kienə & 'dogs' & *'tratti & $>$ 'trettə & 'features' \\
\hline *'pali & $>$ 'pielə & 'poles' & *'baffi & $>$ 'beffə & 'moustaches' \\
\hline${ }^{*}$ sol' dati & $>\quad$ sul'dietə & 'soldiers' & *'pampani & $>$ 'pembənə & 'vine leaves' \\
\hline
\end{tabular}

\footnotetext{
${ }^{29}$ For the presence of the diphthongal outcome of $*[a]$ in closed syllables of verb-forms, see Maiden (1991:183f.).
} 


\begin{tabular}{|c|c|c|c|c|c|c|c|}
\hline *'scru & $>$ & 'sierə & 'whey' & *'senti & $>$ & 'siendə & 'you feel' \\
\hline *'pedi & $>$ & 'piedə & 'feet' & *ker'vellu & $>$ & †ər'viellə & 'brain' \\
\hline *'tremi & $>$ & 'triemə & 'tremble ${ }_{2 \mathrm{sG}}$ ' & *'vekkju & $>$ & 'viekkjə & 'old' \\
\hline
\end{tabular}

What such facts suggest is that, at the period when diphthongization of $*[\varepsilon]$ was taking place, either metaphony of $*[a]$ had yet to occur in closed syllables, or at least that the degree of metaphonic raising of $*[a]$ was considerably lesser in closed syllables and therefore not sufficient to make it input to diphthongization. However we interpret the situation, it is clear that the closed syllable in some sense inhibited metaphony. Milano's analysis (2002:214) of occurrences of raising and fronting of *[a] in historically metaphonizing environments in the Monte di Procida area (Campania) also suggests a preference for open, over closed, syllables. ${ }^{30}$

Finally, indirect evidence that metaphony was originally absent from closed syllables comes from proparoxytones. Even when the stressed syllable of proparoxytones is open, it shows in southern Italian dialects a tendency (discussed in Maiden 1988:23;1991:127f.; also Sánchez Miret 1998:139f.) to resist metaphony, especially if it contains a low mid vowel (particularly a back one). What the stressed vowels of proparoxytones share with closed syllables is a tendency to have a shorter vowel, even in open syllables (cf. Rohlfs 1966:23f.; Castellani 1980b:170f.; Maiden 1988:23; 1991:128; also Hajek and Stevens 2008:519). In many cases, Tuscan proparoxytones with stressed

\footnotetext{
${ }^{30}$ As Milano $(2002: 215 ; 229)$ also points out, however, the proportion of occurrences of metaphony of [a] in environments which would historically have been predicted to trigger it shows no significant difference according to syllable structure.
} 
open syllables lack expected diphthongization: e.g., stomaco 'stomach', pecora 'sheep', lepre (< 'lepore) 'hare', popolo 'people', redina 'rein', opera 'work', tenero 'tender', monaco 'monk', cofano 'coffer', garofano 'carnation'. Several of the foregoing examples lack a historically metaphonizing environment, and/or display mid or low vowels in the penultimate syllable. Where the final vowel would historically have triggered metaphony, and especially where the penultimate vowel could also have triggered it, one tends to find diphthongization: e.g., suocero 'father-in-law' < 'sokeru, but also lievito 'yeast' < *'levitu, tiepido 'lukewarm' (or tepido) < *'tepidu; uomini 'men' < 'omini, tuorlo 'yolk' $<*$ 'torulu, truogolo (or trogolo) 'trug, trough' < *'trogulu. ${ }^{31}$

\section{CORRELATIONS IN TUSCAN BETWEEN ABSENCE OF THE DIPHTHONG AND HISTORICAL}

\section{ABSENCE OF A METAPHONIZING ENVIRONMENT}

\subsection{Absence of the diphthong presupposes original absence of metaphony}

Examination of cases of absence of predicted diphthongs ${ }^{32}$ in Tuscan (and especially medieval Tuscan) clearly supports the view that the diphthongs were originally correlated

\footnotetext{
${ }^{31}$ Certain other exceptions in old or modern Tuscan involve specific phonological environments, as when the vowels appear in hiatus with following /i/: lei 'she', poi 'then', voito 'empty', preite 'priest' (cf. Castellani 1980a:126; 1980b:170).

${ }^{32}$ I have little to say about diphthongization of [0] in modern Tuscan dialects, because most of them systematically have [॰] instead of [wo] (cf. Italian nuovo 'new' vs modern Florentine 'nэvo). In Maiden (1988:13f.) I entertained the idea (see also Rohlfs 1966:106;134) that this absence of the diphthong means that [0] had been resistant in Tuscany ab origine to (metaphonic) diphthongization. The general view, however, is that there has been an organic 'remonophthongization' since medieval times (but see Ventigenovi 1993 for a detailed study of the spread of the monophthong in Florence), and it seems to me
} 
with metaphony: absence of the diphthong repeatedly implies the historical absence of a metaphonizing environment, while the diphthong is (almost) never absent where a metaphonizing environment was historically present. It will be useful in what follows to recognize that the diphthongs may occur either in a historical 'syntagmatically metaphonizing' environment (one in which the stressed vowel was followed by unstressed $[\mathrm{u}]$ or [i]), or in a 'paradigmatically metaphonizing' environment (one in which the stressed vowel occurred in a word-form not itself subject to metaphony but which alternated paradigmatically with a word-form which was so subject). Note, by the way, that I do not claim that original absence of a metaphonizing environment predicts absence of the diphthong in medieval or modern dialects: rather, I claim that absence of the diphthong in medieval or modern dialects points to original absence of a (syntagmatic or paradigmatic) metaphonizing environment. This means that the existence of diphthongized regional or medieval examples such as biene 'well' or nuove 'nine', or of place names such as Siena, merely reflects the undisputed general trend, which is for diphthongization of low mid vowels in stressed open syllables. Such cases in no way contradict my general argument (pace Loporcaro 2011b:122).

5.2 Bene and nove as examples of absence of the diphthong in historically nonmetaphonizing environments

now more likely that the diphthong has simply retreated in recent times. However this may be, medieval Tuscan systematically shows the diphthong in a way fairly faithfully reflected in modern Italian, and the distribution of that diphthong invites a metaphonic interpretation of its origins. 
We may begin with those two causes célèbres of the debate, bene 'well' and nove 'nine' (claims for whose significance as a relic of a stage when the diphthongs were found only in metaphonic environments go back to Schuchardt 1885:8). ${ }^{33}$ However, Loporcaro (2011b:122) explains the absence of the diphthong in these two words as follows:

[S]ince these forms often appear non-prepausally (e.g. nove giorni 'nine days', ben venuto/benvenuto 'well come/ welcome'), their vowels may well not have undergone a change that was crucially conditioned by main stress (as argued by Castellani 1970:169; cf. also Sánchez Miret 1998:171f.).

Loporcaro's point (2011b:692) is not that bene and nove reflect an 'unstressed' variant of these words since, as is well known for Italo-Romance and historically for Romance languages generally, $*[\varepsilon]$ and $*[\supset]$ close to $[\mathrm{e}]$ and $[\mathrm{o}]$ when completely unstressed, so that a genuinely 'atonic' variant of bene and nove would have yielded **'bene and **'nove (Sánchez Miret 1998:145 also takes this view.). Rather, his contention is that diphthongization arises from stressed open syllable lengthening and that such lengthening was maximal in prepausal position. On this view, lack of diphthongization in bene, nove could be explained by their frequent occurrence in a non-prepausal position. However, this idea seems counterintuitive - for bene is a word that in modern everyday speech, at least, is commonly used as an interjection ('well', 'right', 'OK') and therefore frequently occurs 'free-standing', prepausally. The fact that some modern

\footnotetext{
${ }^{33}$ See also Lausberg (1965:248) for a further development of this view, but also Serianni (1999a:109) for an over-hasty dismissal of the idea that these cases are evidence for the role of morphological paradigmatic information in the diffusion of the diphthong.
} 
expressions with prepausal bene, such as va bene ('all right') may have had nonprepausal equivalents in old Tuscan (cf. Castellani 1980d:151, who observes that the old Tuscan equivalent was bene sta), does not mean that prepausal incidences of bene were significantly less common in speech in the Middle Ages than today. For modern spoken Italian the CLIPS (Corpus di italiano parlato) database for 'dialogues' from Florence, Perugia, and Rome actually shows, out of 63 instances of bene, at least 60 that are prepausal.

The issue is not, however, whether bene is less frequent in prepausal position than elsewhere but whether it is significantly less frequent in that position than other items which do undergo diphthongization. The answer seems to be exactly contrary to what one expects given Loporcaro's hypothesis: bene is no less frequent in prepausal position than other items which are regularly diphthongized and, indeed, it actually tends to be more frequent there than these latter.

We have no direct access to medieval spoken Tuscan, and none whatever to the period when the diphthongizations happened. It is possible, however, to gain an approximate idea of where pauses might have fallen by observing punctuation marks such as commas, full stops, exclamation marks, question marks, semi-colons, or colons in texts. Such marks are likely to be the work of copyists or editors, but this does not vitiate this method of identifying pauses. If punctuation marks have been inserted later they are nonetheless independent judgements on the most likely location of pauses in the original texts, had they been read out loud. It might also be objected that thirteenth and fourteenth century written texts are already at a considerable historical remove from the period at which diphthongization emerged in speech. This is true, but for it to be a serious 
objection one would need substantive evidence that bene and other items potentially subject to diphthongization had enjoyed a significantly different distribution in earlier centuries than it had acquired by the thirteenth. This seems doubtful.

Actually, the picture that emerges from, for example, the Pisan Trattati di Albertano da Brescia (1288), from the Novellino (ca. 1300), from Franco Sacchetti (late fourteenth century writings) and from Boccaccio (Decameron, 1370) is that bene is overall more frequent prepausally than other items which actually are subject to diphthongization, such as viene 's/he comes', nuovo 'new', buono 'good', and, most importantly, that it is never significantly less frequent in that position (data from $O V I$ ):

Table 6: Percentage of instances bene, viene, nuovo, buono occurring in apparent prepausal position

\begin{tabular}{lllll}
\hline & bene & viene & nuovo & buono \\
& & & & \\
\hline Trattati di Albertano da Brescia & $19 \%$ & $3 \%$ & $5 \%$ & $10 \%$ \\
& & & & \\
\hline Novellino & $16 \%$ & 0 & $33 \%$ & $12 \%$ \\
& & & & \\
\hline Decameron & $25 \%$ & $20 \%$ & $3 \%$ & $4 \%$ \\
\hline Sacchetti & $37 \%$ & $10 \%$ & $12 \%$ & $12 \%$ \\
& & & & \\
\hline
\end{tabular}

The argument that bene reflects typical occurrence in a pretonic or non-prepausal position would, by the way, gain considerably if there were evidence of some dialect in which bene and biene coexisted and showed, or showed remnants of, a distributional correlation respectively with non-prepausal and prepausal positions. I know of none. The overwhelming tendency in medieval central Italian texts is for bene and biene to be 
mutually exclusive, suggesting that diphthongization, where it occurs (for example, old Perugian), affects this word across-the-board. All in all, the case for bene as a generalized older 'non-prepausal' form lacks support.

It must be mentioned that Castellani (1980d:151; 1980e:168f.; also 1980a:126) appeals, in support of his claim that bene is in origin unstressed, to the fate of its antonym in French, namely mal 'badly' (< Lat. MALE). Since *[a] in original stressed open syllables regularly becomes $[\varepsilon]$ in French (cf. mer 'sea' < Lat. MARE), mal looks like an 'unstressed' variant. This it may be, but there are problems in exploiting this fact to support the analysis of Italian bene as an original atonic or non-prepausal form. French does have diphthongized bien, which suggests that whatever explains the phonological behaviour of mal does not apply to its antonym, and in any case the Textes de français ancien data for the thirteenth century actually suggest that prepausal mal and bien occur in roughly equal proportions (about 6\% of tokens: 39 out of 649 for mal, and 65 out of the first 1000 attestations for bien). The possible differentiatory factor is that mal, unlike bien, is also an adjective in old French, and one that virtually always appears in prenominal (and therefore non-prepausal) position: e.g., mal damage et male perte 'bad harm and bad loss' (Roman de Renart).

What of nove 'nine'? The asymmetry in modern standard Italian in respect of diphthongization between nove and dieci 'ten' is robustly replicated both throughout the history of Tuscan and in those modern dialects of eastern Tuscany and adjacent areas of northern Umbria where the diphthong [wo] is otherwise still preserved (cf. AIS maps 288 nove, dieci and also 1579 nuovo, nuova, nuovi, nuove 'new': only in Cortona does the diphthong appear equally in 'nine' and in all forms of the adjective nuоvo). If the absence 
of the diphthong in 'nine' is to be attributed, as has been argued, to its frequent appearance in non-prepausal position, should we not expect, contrary to fact, exactly the same behaviour of 'ten'? The onus would be on proponents of the 'non-prepausal' account of nove to explain why 'ten' were somehow significantly more likely than 'nine' to appear prepausally, and therefore more liable to acquire the diphthong. It is hard to see what form this explanation would take. Surely, both words are equally liable to be uttered in isolation (e.g., Quanti anni hai? - Nove. / Dieci. 'How old are you?' - 'Nine'. / 'Ten.'). In fact, the distinction between nove and dieci supports the view that the Tuscan diphthongs are historically connected with metaphony, since the former lacks either a 'syntagmatic' or a 'paradigmatic' metaphonizing environment, while the latter ends in [i]. Castellani simply beggars belief when he claims (1980e:170) that nove is 'less widespread, less popular' than dieci and that 'legal, administrative (and also commercial) Latin' bore on the pronunciation of the former rather than on that of the latter. Even Serianni (e.g., 1999b:49), generally uncritical of Castellani's positions on diphthongization, jibs at admitting a non-popular phonological development for basic numerals countable on the fingers of two hands. Incidentally, Rohlfs (1969:312) ascribes the diphthong found in many southern Italo-Romance words for 'ten' to 'Italian influence' (apparently discounting the view that they could be the result of metaphony). On one account, then, 'ten' is 'popular', on the other, apparently, it is not!

It is true that the final vowel of dieci is problematic (see Castellani 1980a:185;187f. for one solution). One would expect final -[e], given the etymon DĔCEM, just as we have nove from Latin NǑUEM. What matters here, however, is that the word for 'ten' does end in -[i], and that there is evidence from across central and southern Italo- 
Romance for its having done so extensively in history. ${ }^{34}$ In most of Lazio, Abruzzo, Campania, and Lucania, we find for 'nine' and 'ten' (AIS map 288) the type 'nove, 'dief', (Serrone, pt 654), 'nэ:və, 'ði:etg' (Gallo pt. 712), 'nэ:ße, 'ti:etf' (Ausonia pt 710), 'nэ:ßə, 'rje:ty' (Ottaviano pt 722), 'no:və, 'di:tə (Spinazzola pt 727). In short, we find in much of upper southern Italy exactly the same asymmetry between the two numerals that we find in Tuscan - and in the south the difference can have no other explanation than metaphony triggered by final [i] in the case of 'ten'. Any notion that this pattern could somehow reflect standard Italian influence, perhaps through schools, or in book-keeping, would need support from evidence of similar influence on other basic numerals. Looking at the numerals 1-20 in central and southern Italy, I see only the most marginal evidence of this, and that only on the periphery of Tuscany (Civitella Benazzone in northern Umbria shows signs of having replaced a diphthongized 'nueve by 'nove; cf. AIS maps 288 and 297, pt 555). In fact, the phonological forms seem overwhelmingly to be those expected locally. Moreover, in those central Italian dialects (including Tuscan) where final $[\mathrm{e}]$ and [i] are usually kept distinct, there is a very strong correlation between the presence of final [i] and the diphthong in 'ten': the type **'detfi is nowhere to be seen in the AIS data for the relevant areas, ${ }^{35}$ so that absence of the diphthong systematically implies final [e].

\footnotetext{
${ }^{34}$ Castellani (1980f:26f.) describes the conflicting opinions of Bembo (who wrote dieci but held diece to be the older form) and Ruscelli (who held dieci to be the older, popular, form). Dieci appears to have been the predominant form in contemporary writers. At any rate, the historical coexistence of a metaphonized *'djetfi and non-metaphonized *'detfe would have favoured the diffusion of the diphthong into the latter.

${ }^{35}$ See also LEI s.v. DECEM. Lindsström (1907) does have 'detfi at Subiaco (Lazio). For some medieval Tuscan examples see Castellani (2000:426f.).
} 
The medieval data for 'ten' in Tuscany and northern Umbria, gleaned from the OVI database, reveal the following occurrences.

Table 7: The word for 'ten' in medieval Tuscan (and Umbrian) texts

$\begin{array}{lllll} & \text { diece } & \text { dece } & \text { dieci } & \text { deci } \\ \text { Arezzo } & 0 & 53 & 0 & 14 \\ \text { Città di Castello } & 0 & 0 & 39 & 0 \\ \text { Gubbio } & 1 & 0 & 0 & 0 \\ \text { Florence } & 2002 & 8 & 834 & 0 \\ \text { Lucca } & 1 & 1 & 39 & 0 \\ \text { Perugia } & 323 & 0 & 1 & 0 \\ \text { Pisa } & 218 & 0 & 97 & 0 \\ \text { Pistoia } & 5 & 0 & 1 & 0 \\ \text { Prato } & 15 & 0 & 0 & 0 \\ \text { Sangimignano } & 13 & 0 & 0 & 0 \\ \text { Siena } & 204 & 2 & 34 & 0 \\ \text { Volterra } & 0 & 0 & 16 & 0\end{array}$

Clearly the diphthong in this word had already become well established, regardless of the nature of the final vowel, but what is striking is that the diphthong consistently appears when the final vowel is -[i]. It is curious that precisely Arezzo should prove the exception, but one can only conclude that dece is there the dominant, indigenous, duly 
unmetaphonized, form, and that it has perhaps analogically evicted the diphthong from a minor by-form in -[i]. Overall, the distinction between nove and dieci found in modern Italian, and extensively elsewhere, is closely consistent with the notion that the diphthong is in origin metaphonic, for only 'ten' has ever had a potentially metaphonizing environment. Those medieval data-sets for which we have large enough samples suggest a situation in which forms with final [e] and [i] both existed. Effectively, by virtue of coexisting with dieci, original dece could be said to have had a 'paradigmatic' metaphonic environment.

\subsection{Absence of diphthongs in historically invariant nouns}

Certain cases of non-diphthongization involve mass nouns which, by virtue of ending in [e] and lacking plurals, are (like bene and nove) morphologically invariant words lacking historical metaphonizing environments, both syntagmatic and paradigmatic. Modern and medieval Tuscan dialects show a significant tendency for the reflex of *'mele 'honey' to be 'mele. For medieval texts (data from $O V I$ ), instances of mele vastly outnumber miele. ${ }^{36}$ In the modern dialects, 'mele (AIS map 1159; $A L I 342)$ is still very widely attested (see also Rohlfs 1966:103f.). Castellani (1980e:167) argues that the lack of a diphthong reflects the fact that the Latin nominative and accusative was MEL, and its genitive, dative and ablative forms had the root MELL- (e.g., genitive MELLIS), ${ }^{37}$ and that it therefore

\footnotetext{
${ }^{36}$ I have discarded cases where mele clearly represents ['mele] 'apples', or where the meaning is ambiguous between 'apples' and 'honey'.

${ }^{37}$ But Castellani (1980g:343) attributes lack of diphthong here simply to long-term preservation of a reflex of MEL without final -e. Russo and Sánchez Miret (2009:171;186) subscribe to Castellani’s view.
} 
contained a closed syllable which inhibited diphthongization. This argument is unconvincing: the etymon is very clearly the neuter nominative-accusative singular MEL, to which has been added the third declension inflexion-class marker -e, yielding *'mele (cf. SAL 'salt' $>*$ 'sale). Melle is indeed occasionally attested in old Tuscan, but Castellani's account implies an implausible scenario in which mele is differentially influenced by melle in respect of its vowel but not of its consonant. Above all, one would expect the reflex of neuter FEL, FELLIS 'bile', to behave identically to MEL, MELLIS in respect of diphthongization, but it does not: virtually everywhere in modern Tuscany we find diphthongized fiele (cf. AIS 140, ALI 345; Rohlfs 1966:104), ${ }^{38}$ and the same is largely true in medieval texts. In thirteenth and fourteenth century Florentine $(O V I)$, we find only two instances of miele vs 154 of mele, while there are 60 attestations of fiele vs 17 of fele. Note, crucially, that while mele is exclusively a mass noun, fiele, in addition to meaning 'bile', is also a count noun meaning 'gall bladder': this means that it contains a 'paradigmatic' metaphonizing environment in the plural (and one that really is used, especially in medical remedies: the fourteenth century Tuscan Ricettario of Piero Ubertino da Brescia has, for example, 16 examples of plural fieli). Neither word shows signs of having contained a closed syllable in the early history of other Romance languages: French, for example, shows diphthongization in miel and fiel. ${ }^{39}$

A further example of a (generally) invariant, mass, noun lacking a metaphonizing environment, and also lacking a diphthong, is the reflex of Latin NIUEM 'snow'. Now this

\footnotetext{
${ }^{38}$ The sole exception is Camaiore (AIS pt 520). Reinhard (1956:8;11) observes that the diphthong is absent in both mele and fele in the dialect of Orvieto (Umbria), but ascribes this to Roman influence.

${ }^{39}$ See, however, Castellani (1980e:167f.) and Sánchez Miret (1998:60).
} 
regularly gives ['ne:ve] in much of Tuscany, with a stressed mid vowel which is clearly not potential input to diphthongization. However, there is abundant evidence (cf. Rohlfs 1966:75) for another protoform *'neve, reflected in Spanish nieve (with similar forms in Aragonese, Occitan, and Ladin), but also in western Tuscany and some areas of Lazio and Umbria (cf. AIS map 378; Reinhard 1956:4). The AIS shows the form ['nje:ve] optionally - on Elba, and there are extensive medieval attestations of nieve from these regions, particularly Siena (see OVI data for nieve). In modern Tuscan dialects where stressed open syllable diphthongization of $*[\varepsilon]$ is otherwise normal, we nonetheless find undiphthongized ['ne:ve] at Vinci, Pisa, Fauglia, Montecatini, Castagneto, Chiusdino, Gavorrano, Scansano, Seggiano, Porto Santo Stefano, and Elba (see also Castellani 2000:289n60).

Reflexes of the Latin adverb FORAS, meaning 'out(side)' historically lack a metaphonizing environment. The type fuora or fuore is found throughout Italo-Romance, including Tuscany. Here, however, the predominant form is fuori, a reflex not of FORAS, but of FORIS 'out(side), out of doors' (cf. Aebischer 1965). In medieval texts from Pisa, the diphthong predominates in both types (some 20 examples without the diphthong, over 1100 with it). Matters are different, however, in medieval Florence: overall, while fuori prevails over fori at a ratio of about 100:1 (5459 vs 57), in fora vs fuora, and in fore vs fuore, non-diphthongized and diphthongized forms occur in roughly equal proportions (43 tokens vs 38 , and 88 vs 90 , respectively). For example, Boccaccio has 424 instances of fuori over 29 of fori, while fore prevails over fuore (37 vs 7$)^{40}$ and fora over fuora (9 vs 3); old Lucchese has 16 examples of fuori but none of fori, while there are nine

\footnotetext{
${ }^{40}$ Both fuore and fore only occur in rhyme.
} 
examples of fuora vs. four of fora, and eight of fuore vs. six of fore. Overall, the distribution of the diphthongs in these words is again that which we would expect if they arose initially in the metaphonic environments and were then gradually diffused into nonmetaphonizing environments.

5.4 Absence of the diphthong in other words historically lacking a metaphonizing environment

In the medieval dialects of Lucca and Pisa, there is a very high incidence of undiphthongized omo 'man' (overwhelming in old Lucchese, and in about $40 \%$ of the examples in old Pisan), rather than uomo. In contrast, the diphthong occurs in the proparoxytonic plural $(u)$ omini (with potentially metaphonizing posttonic [i]) by a ratio of 2:1 in old Pisan, and 1:1 in old Lucchese (to the extent to that the diphthong is absent in the plural, this can be attributed both to the analogy of the singular and to the resistance in Tuscan of proparoxytones to diphthongization). Castellani (1980g:343; 2000:287, and as 'Ventigenovi' 1993:170f.) ascribes the (h)omo type in these varieties to a Latin model, but one could scarcely imagine a less likely candidate for learnèd influence. This form is strongly consistent with the notion of a historical correlation between the diphthong and metaphony, since the etymon HŎMO lacks a potentially metaphonizing environment. It must be recognized, though, that a contributory factor may have been the frequent use of this word in old Tuscan (cf. Egerland 2010) as an unstressed indefinite pronoun 'one'.

The medieval Tuscan reflex of Latin RŎTA(M) 'wheel' is usually the expected ruota (and plural ruote). There is, however, a very high incidence of non-diphthongized 
rota and rote. In texts from Pisa ${ }^{41}(O V I)$ there are 72 instances of rota $-e$, against 58 of ruota, $-e$, while in contrast undiphthongized feminine bona $-e$ 'good' and nova $-e$ 'new' form a tiny minority compared with diphthongized buona, $-e$ and nuova, $-e$ (respectively, 41 vs 1199 and 40 vs 317). This general picture is entirely borne out for Pisan by the writings of Francesco di Bartolo da Buti (1395). ${ }^{42}$ In the writings of the Florentine Franco Sacchetti, there are 17 instances of rota, $-e$ vs four of ruota, $-e$ whilst, in contrast, buona, - $e$ and nuova, $-e$ vastly predominate over bona, $-e$ and nova, $-e$ (129 vs two, and 153 vs 24 , respectively). The link with metaphony is suggestive: the word for 'wheel' never had a potentially metaphonizing environment in its paradigm, while the feminine adjective 'good' and 'new' were 'paradigmatically' metaphonic, alternating with masculine forms subject to metaphony.

A similar example from modern Tuscany, again involving a feminine noun historically lacking a metaphonizing environment, is undiphthongized ['me:ta], meaning 'stack of corn, pile', and widely attested in the provinces of Arezzo, Livorno, and Lucca (cf. ALT question 132d).

\footnotetext{
${ }^{41}$ Medieval western Tuscan dialects tended to monophthongize [wo] after [r] in cases such as trova 'he finds', for truova, a tendency that around the turn of the fifteenth century spread to Florentine (see (e.g., Manni 1979:120-22; Castellani 1980f:18-24; Serianni 1999b:49f.). But, as modern standard Italian shows (e.g. trova 'he finds' vs ruota), this phonological change is triggered not by preceding [r] alone, but specifically by $\mathrm{Cr}$ clusters. It does not seem that a phonologically conditioned monophthongization is at work in these Pisan examples in the case of $r(u)$ ota.

${ }^{42}$ Even allowing for forms which are in fact quoted from Dante and not necessarily reflective of the author's usage.
} 
5.5 Absence of the diphthong in verb-forms historically lacking a metaphonizing environment

Few examples of an undiphthongized low mid vowel come from the verb. This is exactly what we would expect, given that virtually all verb-forms at least had one 'paradigmatic' metaphonizing environment, namely second person singular forms in -[i]. Yet there are two kinds of verb-form which do not, or did not originally, have such an environment namely impersonal verbs lacking second person forms, and those whose second person singular ending was originally *-as - and it is precisely among such forms that the diphthong is sometimes absent. The example of the first kind is Latin PLUUERE 'rain', which yielded Romance *'plovere and whose sole finite form in normal usage is third person (e.g., modern Italian piove 'it is raining', subjunctive piova). In the thirteenth and fourteenth century Tuscan texts in $O V I$, there are only seven attestations of piuove (five) or piuova (two), five of them from Siena. Now it is true that in the history of Tuscan and in Italian the diphthong [wo] tends to be replaced by [0] when immediately preceded by a palatal consonant or glide (e.g., modern standard Italian gioco 'game', figliolo 'son', for older giuoco, figliuolo), and it is also true that this phonological retreat of the diphthong is sporadically observable from the thirteenth century (cf. Castellani 1980a:126; 'Ventigenovi' 1993:182f.). However, in medieval Tuscan texts which consistently show piove, piova this phonological effect is at best only sporadic in other post-palatal environments, whereas absence of the diphthong is systematic in these two words. For example, Sacchetti (Trecentonovelle) has only piove, piova, but hundreds of examples of the type figliuolo 'son', figliuola 'daughter', figliuoli, figliuole and none of figliolo, etc., or giиосо 'game', 'I play', giuochi 'games', 'you play', giuoca(no) ‘he plays (they play)', 
exceeding forms in gioc- by well over three to one..$^{43}$ Actually, many instances of piova and piove in medieval Tuscan are not in fact verbs but the singular and plural forms of the noun meaning 'rain' (just over half of a total of 576 occurrences of these forms are nouns, and virtually all attestations of piova are nouns). Since these nouns, too, would never have contained any potentially metaphonizing environment, their lack of a diphthong is fully consistent with the hypothesis that the absence of the diphthong reflects the original absence of a metaphonizing environment.

Modern Italian fails to display the predicted diphthong in the rhizotonic forms of the imperfect indicative of essere 'be': 1SG 'cro 2SG 'eri 3SG 'cra 3PL 'crano. The expected iera, etc., is indeed attested in medieval Tuscan (e.g., Castellani 1980a:131), but is everywhere vastly outnumbered by the type era, presumably pronounced 'cra. One cannot simply ascribe this fact to the frequent occurrence of this verb in 'unstressed' positions (it is true that it often functions as an auxiliary or as a copular verb followed by a more heavily stressed non-finite verb-form or predicate), since the 'unstressed' alternant of $[\varepsilon]$ is $[\mathrm{e}]$, as in modern Italian 1PL era'vamo. One could claim (as for bene above; see, e.g., Serianni 1999b:48f.) that the diphthong originated under phrasal stress, and failed to appear in era because this verb was so often not in phrasal-stress position but there is a dearth of evidence, and I detect no sign, in those early texts where both forms occur, of any correlation with phrasal stress. Another difficulty with the argument from phrasal stress is that one would expect similar resistance to diphthongization in, for example, modal verbs, which are usually non-prepausal because they are followed by an

\footnotetext{
${ }^{43}$ Cf. also Boccaccio, who only ever uses piove, piova, but has piuolo 'rung, peg' (in Epistola a Pino de' Rossi, alongside hundreds of examples of figliuolo, etc.).
} 
infinitive or by some other complement bearing phrasal stress: but to my knowledge volere 'want' and potere 'be able' have always shown the expected diphthong (in the third person singular present indicative) as much under phrasal stress (Che vuole? 'What does he want?'; Non può(te) 'He can't') as in the very common contexts of a following infinitive or object complement (Vuole / Può venire 'He wants to / can come'; Vuole una risposta 'He wants a reply.'). Now the regular, and historically underlying, continuant of Latin 2SG ERAS was not the modern eri, but ere, where -[e] is the phonologically regular development of Latin -AS (for this claim, see for example Rohlfs 1968:248;293, Vanelli 2010:1433f., and particularly Maiden 1996). In fact, the lack of a diphthong in Tuscan resonates exactly with the exceptional lack of metaphony in second person singular 'cri in various modern southern Italian dialects (e.g., AIS points Norcia 576, Serrone 654, Nemi 662, Sonnino 682, and Vernole 739), where we may assume that the form was originally *'cre (preserved in Calabria: e.g., Mangone, pt 761). Note that the second person singular present tense form of this verb $(<*$ sci) does undergo metaphony in these dialects, so one cannot easily attribute its absence in the imperfect to a propensity for the verb 'be' to occur unstressed.

There are at least another three ${ }^{44}$ verbs in modern Italian which fail to show expected diphthongization. One of these seems to contradict my general hypothesis, namely fourth conjugation coprire 'cover'. But however one seeks to explain it, the lack of the diphthong in this case is demonstrably a recent development, uo being robustly

\footnotetext{
${ }^{44}$ Possible other examples are first conjugation rimproverare 'reproach' (e.g., 3SG.PRS.IND rim'provera) and vomitare 'vomit' (e.g., 3SG.PRS.IND 'vomita), but the fact that these forms are proparoxytones (see section 4) may be relevant.
} 
present in medieval texts. For thirteenth and fourteenth century texts $(O V I)$ from Florence, there are 148 occurrences of cuopr-vs. 27 of copr- (and in these latter we cannot be sure of the quality of the vowel, which could be [o] rather than [o]); in texts of the same period from Pisa there are 60 examples of cuopr- and four of stressed copr-. The remaining two cases are first conjugation levare ${ }^{45}$ 'raise, remove' (e.g., 3sG 'leva) and rinnovare 'renew' (e.g., 3SG rin'nova), and there is also historical evidence for such a development in negare ‘deny' (see Serianni 1999b:50). In medieval Florence and Pisa the stressed root, written lev-, considerably outnumbers liev- (for modern Tuscany see, e.g., AIS map 1562). The preference for the undiphthongized forms is less clear-cut in the medieval documents for $\operatorname{rin}(n) u o v-$ vs $\operatorname{rin}(n) o v a-$, but nonetheless present. Why levare and rinnovare in particular, among first conjugation verbs, should fail to display the expected diphthong is, admittedly, an enigma, especially given the existence of semantically and formally related adjectives lieve 'light' and nuovo 'new', which systematically show it (see also van der Veer 2001:179;195). But it is significant that these are first conjugation verbs, that is, verbs that would have had no metaphonizing environment in their present indicative ${ }^{46}$ (the second person singular ending -AS would have originally yielded $-[\mathrm{e}]$, as explained above). Note also, in this connexion, that in some southern Italian dialects there is evidence of early failure of first conjugation verbs

\footnotetext{
${ }^{45}$ Pollidori Castellani (1961) ascribes leva to the analogy of unstressed forms (see also Rohlfs 1966:103), but the stressed vowel is not the [e] of the unstressed root, but $[\varepsilon]$. Note also the noun leva ('leva) 'lever', which is apparently derived from the verb (although conceivably the verb could be derived from the historically unmetaphonized noun).

${ }^{46}$ The only root-stressed parts of these verbs to have had the desinence -[i] in the second person singular would have been the present subjunctive.
} 
to undergo metaphony. Specifically, in Francavilla Fontana (Salento; see Ribezzo 1912:29,33; Mancarella 1970:121-23; 1998:92f.; also Fanciullo 2014:92f. for a possible case in Latiano $)^{47}$ first conjugation verbs originally containing high mid vowels show not the expected metaphonic output of high mid vowels, but that of low mid vowels, involving diphthongization: e.g., 'sjekki 'you dry' < *'sekki, ar'dweri 'you smell' < $*_{0}$ 'dori. A possible interpretation of these facts (see also Maiden 1986:181) is that when metaphony applied to high mid vowels there was as yet no metaphonizing environment in such verbs (the $2 \mathrm{SG}$ present indicative ending being $*_{-[\mathrm{e}]}$ ). The chronologically later operation of metaphony of low mid vowels (see Maiden 1987), acted after the desinence [e] had been replaced by -[i], and after stressed high mid vowels have been independently lowered. Consequently, first conjugation verbs with original high mid vowels show low mid vowel metaphony in these dialects. At any rate, something has impeded the expected operation of metaphony in first conjugation verbs in a way not found in other conjugations, and one strongly suspects that the culprit is the historical lack of a metaphonizing environment.

\footnotetext{
${ }^{47}$ Fanciullo's recent detailed re-reading and reinterpretation of Ribezzo overlooks the crucial detail that these unexpected metaphonic outputs are practically limited to the verb, and systematically sensitive to conjugation class (see, e.g., Fanciullo 2014:98). Fanciullo also cites what is apparently the reverse effect, in verbs containing historical low mid vowels showing the metaphonic reflexes of high mid vowels, but he does not mention that these are limited to non-first conjugation verbs (or that they form part of the geographically much wider phenomenon described, for example, in Maiden 1985; 1989; 1991). That first conjugation verbs do not participate in this latter phenomenon is, in fact, also evidence that in this dialect they were originally exempt from otherwise general metaphonic processes.
} 


\subsection{A case of lack of diphthongization in a historically metaphonizing environment?}

Rohlfs (1966:104) lists certain other, sporadic, examples of the absence of diphthongization of $*[\varepsilon]$ in Tuscan. He observes an imperative 'sede 'sit' in Casoli (Versilia), but the ending -e is historically expected (< SEDE), and high frequency imperatives do frequently show a degree of autonomy (cf. Maiden 2007) from other parts of the paradigm (I see no reason for Castellani's assumption 1980a:132 that this form reflects an 'Emilian-Ligurian' pronunciation). Rohlfs also comments on the absence of diphthongization in the second person plural present indicative form of the verb 'to be', namely 'scte (cf. Italian siete) at various localities in Tuscany. Given the high degree of intraparadigmatic autonomy of forms of the verb 'to be', and that the ending -te is not a metaphonizing environment, the resistance of these forms to diphthongization is unsurprising. Castellani (1980a:132) ascribes this form to the influence of undiphthongized 2SG sei. The undiphthongized 'venere (< Lat. UENEREM), an old name for 'Friday' in Garfagnana and the provinces of Pisa and Livorno (cf. also ALT question $25 \mathrm{c})$, is in origin a singular proper name and probably a morphologically invariable form with a non-metaphonizing final vowel, and is in any case a proparoxytone, and therefore liable not to diphthongize. Undiphthongized 'sspe 'hedge', heard in Santa Maria del Giudice, is, again, isolated, however one explains it, and the linguistic atlases for Tuscany systematically show diphthongization, or its effects, in this word.

There is just one substantive counterexample to the claim that a historical syntagmatic metaphonizing environment predicts a Tuscan diphthong. This involves the verb 'come' in Stazzema (Lucca). In Pomezzana di Stazzema Rohlfs (1966:104) reported hearing 2SG imperative 'veni 'come' (<*'veni), and indeed this form recurs both in the 
imperative and in the second person singular present indicative in $A L E I C$ maps 1481 and 690 (pt 55 Stazzema). This dialect also has undiphthongized 3SG present 'vene (ALEIC maps $142 ; 147 ; 181 ; 308$, a form also mentioned by Rohlfs for Elba, and confirmed for that island by $A L E I C)$. In general, Stazzema systematically shows diphthongization of *[ع] in stressed open syllables (see, e.g., ALEIC maps $145,157,923,1885$ ), and the unexpected absence of the diphthong seems limited to this one lexeme. Now elsewhere in Tuscany this verb is a locus of analogical levelling of the root vowel, inlcuding extension of the diphthong into root allomorphs containing closed syllables: e.g., first person singular present 'vjengo for 'veygo at Incisa (AIS pt 534) and Castagneto Carducci (AIS pt 550). A possible explanation of what we observe in Stazzema might therefore also appeal to analogical levelling for this verb, either extension of the root vowel of closedsyllable allomorphs such as 'vengo or, quite possibly, a hypercorrect reaction to earlier generalization of the diphthong, in which $[j \varepsilon]$ is replaced by $[\varepsilon]$ even in stressed open syllables. Elsewhere in Tuscany, it is sometimes the entire 'veng- root which is analogically extended, albeit only into the second person singular (see AIS 1695). The morphologically very similar verb tenere 'hold' also shows analogical ousting of the diphthong in Stazzema, but in this case the prevailing form is the unstressed alternant [e]: second and third person singular 'teni and 'tene (ALEIC maps 189, 758), vs. general Tuscan 'tjeni, 'tjene.

Overall, the Tuscan exceptions to diphthongization consistently point in the same direction: they are correlated with the historical absence, syntagmatic or paradigmatic, of a metaphonizing environment. The diphthong is always present when a metaphonizing environment (syntagmatic or paradigmatic) was historically present. The inference must 
then be that the diphthong originates in metaphony, and that its extension into historically non-metaphonizing environments was favoured in words which alternated with metaphonized forms, and impeded in those that did not.

\section{THE MECHANISM OF DIFFUSION OF STRESSED OPEN SYLLABLE DIPHTHONGIZATION}

The Tuscan diphthongs are significantly correlated with a metaphonic origin, but we still have to explain how they have come to appear outside historically metaphonizing environments. I believe (as I argued in 1988) that an answer to this question lies in the distribution of the diphthongs in modern northern Italo-Romance dialects (particularly in the Piedmontese and Lombard Alps, in an area roughly bounded by Lake Maggiore, Cuneo, Turin, Milan, and Biella). In a nutshell - and as I demonstrate in more detail shortly - the initial motor of the spread of metaphonic diphthongs outside the historical metaphonic environment in the northern dialects was none other than metaphony itself, and specifically a relexation in its conditioning environment. These effects are today most noticeable for stressed $*[0],{ }^{48}$ especially evident in areas of Piedmont and Lombardy (see also Ascoli 1873:277; Salvioni 1886:202; Toppino 1905; Spoerri 1918; more generally Maiden 1988:14-19, Sánchez Miret 1998:195f.). Thus Valle Mesolcina (where [wo] > [e]; Camastral 1959): fek 'fire' (<*'foku); nef 'new' (<*'nэvu, i); mef or mof 'move ${ }_{3 \mathrm{SG}}$ ' $(<*$ 'move); pjef or pjof 'it rains' (<*'plove); 'Jkela or 'Jkola 'school' (<

${ }^{48}$ In a number of Ligurian dialects (e.g., AIS map 18, pt 177 Sassello, pt 178 Genova, pt 190 Airole, pt 193 Borgomaro, and elsewhere) the reflex of Latin nominative singular NEPOS 'nephew' is 'ne:vo or 'ne:vu, without trace of diphthongization. The same word, whose Romance etymon is presumably *'ne:vo rather than ***ne:vu, also conspicuously escapes metaphonic diphthongization in Romansh (Eichenhofer 1999:70). Cf., however, Schürr (1970b:6). 
*'skola); 'roda 'wheel' (< *'rota); 'mola 'whetstone' (< *'mola); 'noda 'swims' (< *'nsta). The data from the Atlante linguistico italiano for Alpine Piedmont and Lombardy confirm this picture:

Table 8: Distribution of diphthongization of [०] ('+' = diphthong or reflex thereof; '-' = no sign of diphthong)

\begin{tabular}{|c|c|c|c|c|c|c|c|c|c|c|}
\hline & Livigno & S.Antonio & Voltorre & Galliate & Balocco & Rueglio & Vercelli & Crescentino & Asti & Saluzzo \\
\hline *'ovu & + & + & + & + & + & + & + & + & + & + \\
\hline \multicolumn{11}{|l|}{ 'egg' } \\
\hline *'foku 'fire' & + & + & + & + & + & + & + & + & + & + \\
\hline *'nove 'nine' & + & + & + & + & + & $?$ & + & + & + & + \\
\hline *'kore 'heart' & - & - & + & + & + & + & + & + & + & + \\
\hline *'vole 'wants' & - & - & + & + & + & + & + & + & + & + \\
\hline *'rota 'wheel' & - & - & - & - & - & + & - & - & - & - \\
\hline *'nora & - & - & - & - & - & - & - & - & - & - \\
\hline \multicolumn{11}{|l|}{ 'daughter-in- } \\
\hline \multicolumn{11}{|l|}{ law' } \\
\hline *'skola & - & - & - & - & - & - & - & - & - & - \\
\hline
\end{tabular}

Some Ladin dialects similarly show the pattern of exceptionless diphthongization in open syllables in originally metaphonizing environments, almost exceptionless diphthongization before original unstressed mid vowels, but frequent absence of the 
diphthong before [a] (cf. Heilmann 1955:58; Kramer 1977:76-81; Maiden 1988:18). Ladin also shows frequent absence of the diphthong in reflexes of *'soro 'sister' < Latin nominative SOROR: cf. AIS map 14; Kramer (1977:78). Old French (cf. Spore 1972:7379) also shows resistance to diphthongization before [a], at least for the back vowel (e.g., mole or meule 'whetstone', roue 'wheel'). In some northern Italo-Romance varieties the same developments percolate into closed syllables as well, but this time exclusively in the metaphonic environment. Thus Mesolcina (Camastral 1959:123f.): kel 'neck' (<*'ksllu), kern 'horn' (<*'kornu), sen 'sleep' (<*'sonnu); see further Maiden (1988:12). In the archaic Gallo-Italian dialect of Trecchina (Gulf of Policastro in southern Italy) there is not only generalized open syllable diphthongization (e.g., 'fuora 'out' < *'fora, 'cuove 'it rains' < *'plove, 'tiene 'he has' < *'tene), but also metaphonic diphthongization before final unstressed -[i] in a'pierti < *a'perti 'open', 'jienki 'bullocks' < *jo'venki, 'muorti 'dead'<*'morti, 'gruossi 'big' < *'grossi. ${ }^{49}$ Trecchina also shows diphthongization in closed syllables before palatals, e.g., 'viecca 'oldFSG'< *'vettfa < *'vekla, 'kuoKu 'I gather' $<*^{\prime}$ koKKo < COLL(I)GO. Palatal consonants favour diphthongization in closed syllables in various northern Italian varieties (see Spoerri 1918:400; Sganzini 1928:157f.; Maiden 1988:25) and notably also in French: e.g., tiers 'third' < *'tcrtju, nièce 'niece' < *'neptja, lit 'bed' < *ljejt < < *'lektu, pis 'udder' < *pjejts <*'pektu. In addition, various northern Italian varieties show the effects of metaphonic diphthongization in closed

\footnotetext{
${ }^{49}$ The fact that metaphony is restricted to the historical environment of final -[i] is characteristic of many northern Italian dialects (cf. Maiden 1987). It is also a reasonable guarantee that the diphthongization in closed syllables is not due to the surrounding southern Italian dialects.
} 
syllables, specifically where the intervening consonant is /ll/ (cf. Spoerri 1918:400; Gysling 1929:129f.; Camastral 1959:123f.).

These data suggest a scenario in which diphthongization commences in metaphonic environments, and just in open syllables. They also suggest a phonologically motivated further extension of the diphthongs, along two routes (see also Rohlfs 1941:85). The diphthong percolates initially into the final-vowel environment phonologically closest to the original metaphonizing environment (namely mid vowels); ${ }^{50}$ this general (but at first contextually conditioned) spread of the diphthong in place of low mid vowels ultimately becomes a matter of general substitution of low mid vowels in open syllables, affecting also open syllables before final [a], but sporadically leaving some forms in stressed [o] unaffected (this asymmetry between front and back low mid vowels is, by the way, also sometimes characteristic of metaphony - see Maiden 1988:23f.). However the diphthong also percolates into closed syllables in certain phonological environments (involving raising of the tongue body) which were most articulatorily similar to the original conditioning environment for metaphony. In short, the imprint of original metaphonic conditioning of the diphthongs is omnipresent in northern Italian varieties and beyond.

The northern Italo-Romance facts, however, also show clear signs of the role of morphology in favouring or impeding diffusion of the diphthong. It is surely no coincidence that nearly all cases of blockage of metaphonic alternation before final

\footnotetext{
${ }^{50}$ Note, by the way, that this extension in the conditioning environment for metaphony could not also affect high mid stressed vowels, since for metaphony to operate the conditioning environment has to be articulatorily higher than the input vowel.
} 
unstressed [a] occur in nouns which historically lacked alternating masculine forms containing potential metaphonizing environments. Adjectives are a different matter: if

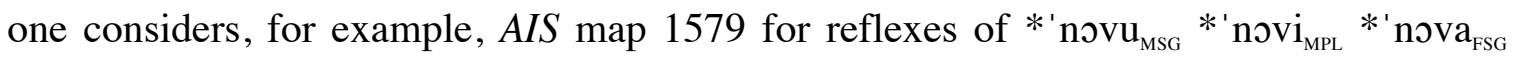
*'nэve ${ }_{\mathrm{FPL}}$ 'new', one finds places where the diphthong is still limited to the original metaphonic environment (the case in several alpine Piedmontese and Ticinese dialects:

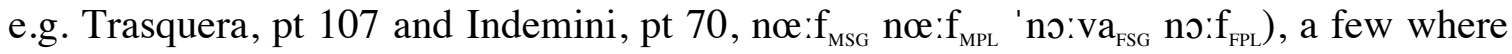
the diphthong has extended to the feminine plural before -e (e.g., Premia nœ: $f_{\mathrm{MSG}}$ 'no:va ${ }_{\mathrm{FSG}}$ ... nœ: $\left.f_{\mathrm{FPL}}\right)$, but mostly one finds the diphthong present throughout the paradigm, even in localities where reflexes of words such as *'fora 'outside', *'rota 'wheel', or *'nora still lack it: e.g., Desana (AIS pt 149) 'fo:ra, 'ro:va, 'no:ra, but 'nœ:va ${ }_{\mathrm{FSG}}$. See also Kramer (1977:76) and Heilmann (1955:58) for observations on the historical role of morphological analogy in the redistribution of diphthongization in Ladin.

It is not easy to reconcile such facts with the alternative view that the diphthongs are unconnected with metaphony and are, rather, a 'spontaneous' development of the low mid vowels in stressed open syllables. To do so one has to find some property of nonhigh final unstressed vowels which would make the vowel of an open stressed syllable in some respect more like that of a closed syllable, and therefore less susceptible to diphthongization. Pellegrini (1982:17), and Zamboni (1993:467), proposed that the greater number of syllables in proparoxytones and words retaining final vowels (principally final [a], unlike other final unstressed vowels, is not generally subject to deletion in northern Italy) led to a compensatory shortening of stressed vowels in such words: but for such an observation to be applicable to the diphthongization of the low mid vowels we would have to suppose that such diphthongization postdated deletion of 
final unstressed vowels other than [a] - a phenomenon which in northern Italy seems fairly recent and is by no means complete everywhere. Sánchez Miret (1998:200f.) claims that an intrinsically greater length of final unstressed low vowels over that of other final unstressed vowels favoured a lesser duration in the preceding stressed vowel, which in turn would have disfavoured diphthongization. ${ }^{51}$ The fundamental problem with arguments of this kind is the lack of any robust, independent, empirical support. If final unstressed [a] really had the differentiatory effect attributed to it, we might expect to witness the same effect in other phenomena involving diphthongization of stressed vowels, such as the closing diphthongization of stressed *[e] and *[o] to *[ei] and *[ou], encountered in the history of French and other northern Gallo-Romance dialects, Francoprovençal, Romansh, Friulian, the dialects of much of northern Italy, coastal areas of south-eastern Italy, and Vegliote (e.g., Bolognese *'tela > 'taila 'canvas'; *a'more > a'maur 'love') or the raising and fronting in French and some northern and southern Italo-Romance varieties (see, e.g., Sánchez Miret 1998:217; Loporcaro 2011b:138) of [a] to $[\varepsilon]$ in open syllables (e.g., MARE $>$ mer 'sea'), possibly via a diphthongal stage *[ae]. To the best of my knowledge, none of these developments shows any clear sign of sensitivity to the identity of the final vowel. ${ }^{52}$ Moreover, Sánchez Miret's claims for a

\footnotetext{
${ }^{51}$ Sánchez Miret in fact identifies a number of other contextual hierarchies affecting vowel duration, but the one that is directly relevant here involves the effect of the height of final unstressed vowels on the duration of stressed vowels.

${ }^{52}$ Sánchez Miret (1998:196f.) does cite a single pair of possible examples from French dialects of Doubs (suffix -eux <-OSUM vs oure 'hour' < HORAM), Saône-et-Loire (suffix -eu <-OSUM vs -ouse <-OSAM) and Champagne (seul < SOLUM vs sole < SOLAM), plus some examples from French (e.g., louve 'she wolf' < LUPAM, couve 'broods' < CUBAT) which may, however, be influenced by the following labial.
} 
reduced durational effect of final [a] is based not on any direct evidence from anywhere in modern or medieval Italo-Romance, but - as he acknowledges - on a slight effect of this kind, which he detects in experimental data provided by Navarro Tomás (1916) for Spanish word-forms (pronounced in isolation), and in some data from Canary island Spanish (see Sánchez Miret 1998:201); Sánchez Miret (1998:201) holds out the promise of future experimental confirmation, but I am unaware that any has appeared (see, e.g., Russo and Sánchez Miret 2009:166; also van der Veer 2006:20). One can only repeat that what the northern Italian data show is a very robust correlation between the diphthong and historical environments involving a following raised tongue body. The further away one gets in phonological space from environments of this kind, the less stable the incidence of diphthongization becomes. We also know that (despite claims to the contrary) the diphthongs really are a regular reflex of metaphony of low mid vowels. There is every reason to believe that the pattern of low mid vowel diphthongization found in northern Italy originates in metaphony, and it seems entirely plausible that the Tuscan facts could have a similar explanation, even if it is not clear whether Tuscan shared in the

original phonological motivation for the spread of the metaphonic diphthong, or merely 'joined' in a trend for substitution of the low mid vowels by diphthongs, emanating from the north.

\section{THE WIDER ROMANCE CONTEXT}

\subsection{The diphthongs outside Italy}

My focus hitherto has been almost exclusively on Italy, and principally on Tuscan. But the opening diphthongs have a much wider Romance diffusion, and outside Italy the 
correlations between metaphony and diphthongization are generally much less apparent. Let us suppose, as often argued (e.g., Loporcaro 2011b:134f.), that there really was a general 'Romance opening diphthongization' independent of metaphony, and that what we observe in Tuscany (and in northern Italy) is in some sense the result of propagation of this 'Romance diphthongization', unconnected with metaphony, into the ItaloRomance domain. ${ }^{53}$ The strong distributional correlations with metaphony, described at length above, would still need an explanation, and it is hard to see any alternative to saying that a 'coincidence' in output between the general Romance diphthongization and metaphonic diphthongization favoured a redistribution of the latter. ${ }^{54}$ The need to appeal to the historical role of metaphony would remain, even under such a scenario. I am not, however, convinced that the wider Romance picture is incompatible with a metaphonic origin.

We do not have an absolute chronology for metaphony, but nothing prevents us from saying that it arose very early in the history of the Romance languages, and early enough to have yielded diphthongs from $*[\varepsilon]$ and $*[0]$ very widely across the Romance domain. If so, then the scenario we reconstruct for central and northern Italy could have

\footnotetext{
${ }^{53}$ De Angelis (2014:54f.) discerns evidence for Loporcaro's general position in the fact that generalization of the diphthong in Tortorici (in the province of Messina, Sicily) seems due to the influence of neighbouring dialects of northern Italo-Romance origin with generalized diphthongization, rather than to the spread of the indigenous metaphonic diphthong. But these are recent phenomena specific to Sicily and do not necessarily throw any particular light on the Tuscan situation.

${ }^{54}$ Van Coetsem and Buccini (1990:211) speculate that general stressed syllable diphthongization could represent a 'reconditioning' of metaphonic diphthongization, but they give no clear account of how or why such 'reconditioning' could have occurred.
} 
existed much more widely. Gallo-Romance (especially northern varieties) essentially shows the diphthong restricted to open syllables, and also occurring in closed syllables where a palatal followed, effectively the situation observed in many modern Alpine ItaloRomance varieties, and therefore susceptible of the same kind of interpretation - as the outcome of a gradual extension of metaphony. Where the diphthong occurs in closed as well as open syllables (e.g., in Castilian, and in Romanian for front vowels) we might still assume a metaphonic origin (perhaps in these cases metaphony had already percolated

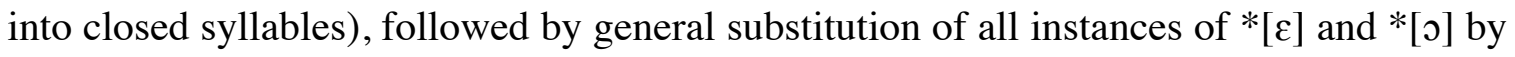
the diphthong. In the Castilian and Romanian cases some crucial evidence is, admittedly, lacking, in that one does not detect there any traces of impedance of diphthongization in historically non-metaphonizing environments, but that does not preclude a metaphonic explanation. The objections to a 'metaphonic' account are of a different kind: namely that there is indeed evidence in the relevant languages for metaphony of low mid vowels, but that what that metaphony produces is not diphthongization.

7.2 Apparent discrepancies between Ibero-Romance diphthongs and the output of metaphony

For Ibero-Romance, Loporcaro (2011b:693) mentions varieties of Astur-Leonese which have forms such as puirtu 'port' and fuibu 'fire' (cf. Castilian puerto, fuego), as evidence of the historical distinctness of metaphony from diphthongization, since the diphthong [we] appears itself to have been input to metaphonic raising. What one has to be able to rule out, however, is the possibility that here the metaphonic process persisted for long enough to be able to apply to its own output (cf. García Arias 2003:126f., who postulates 
the operation of a 'second metaphony' in Asturian). In any case, the process of metaphony seems able to endure over centuries, potentially re-applying to its own output, and there are regions in the Romance world, such as south-eastern Salento (Grimaldi 2003; Loporcaro 2011b:133f.), and Logudorese Sardinian (Loporcaro 2011b:127), where metaphonic raising of low mid vowels continues to be a live process.

More problematic is the phenomenon, prominent in Castilian, of raising of the low mid vowels to [e] and [o], rather than diphthongization (cf. also Penny 2002:51-54. This occurred before original unstressed [i], or yod (for reasons for postulating a historically underlying yod, see particularly Barbato 2012):

Table 9: Metaphonic raising in Castilian

\begin{tabular}{llll}
\hline SPECULU(M) & $>$ *es'peilo $>$ espejo 'mirror' \\
\hline PECTUS & $>$ *'peito $>$ pecho 'chest' \\
\hline *'nervju & $>$ *'nervjo $>$ nervio 'nerve' \\
\hline UENI & $>*^{\prime}$ 'veni $>$ ven 'come!' \\
\hline OCULU(M) & $>*^{\prime 2}$ illo & $>$ ojo 'eye' \\
\hline NOCTE(M) & $>$ *'noite $>$ noche 'night' \\
\hline
\end{tabular}

This development suggests that metaphony produced raising of low mid vowels, and must have operated prior to, and therefore have 'bled' (removed potential input to), diphthongization of low mid vowels. The latter would then, consequently, have to be independent of metaphony. But these facts need a broader, comparative, perspective. In French (and Occitan, Catalan, Romansh, and northern Italy — see below) much the same 
set of environments and conditions yields diphthongization of low mid vowels in closed syllables (table 10; see also Lausberg 1965:§205). That the historically intervening stage in Gallo-Romance was indeed a diphthong is shown by Occitan, where the palatal environment is the primary locus of diphthongization - lieit, cueit, uelh.

Table 10: Diphthongization before original yod in French

\begin{tabular}{|c|c|c|c|c|c|}
\hline LĔCTUM & $>$ & *'1eitu & $>$ & *'ljeit & $>\quad$ lit 'bed' \\
\hline *'neptja & $>$ & & & *'njetja & $>$ nièce 'niece' \\
\hline TĔRTIAM & $>$ & & & *'tjertja & $>$ tierce 'third hour' \\
\hline NŎCTEM & $>$ & *'noite & $>$ & *'nweit & $>$ nuit 'night' \\
\hline ŎCULUM & $>$ & *'silu & $>$ & *'we $\hat{\text { ' }}$ & $>$ ail 'eye' \\
\hline
\end{tabular}

Here we see that where Castilian raised, French (with Occitan and Catalan; cf. Fouché 1925:5) diphthongized. It is unlikely to be a coincidence that both in Ibero-Romance and Gallo-Romance, and beyond, $*[\varepsilon]$ and $*[\circ]$ underwent an otherwise abnormal ${ }^{55}$ development in much the same phonological environment - and it is an environment very close in articulatory terms to the normal environment for metaphony. In Occitan, indeed, an additional locus of diphthongization (Lausberg 1965:\$200; Schürr 1970b:74f.) appears to be $[\mathrm{w}]$ or $[\mathrm{u}]$ in immediate contact with the vowel, in other words an environment similar, in articulatory terms, to [u]; cf. also Schürr (1970b:47) for parallels

\footnotetext{
${ }^{55}$ Spanish does not otherwise raise low mid vowels, and Gallo-Romance does not otherwise diphthongize in stressed closed syllables.
} 
in Romagnol. ${ }^{56}$ The comparative evidence seems consistent with the notion that both diphthongs and raised vowels are possible, and historically linked, outcomes of metaphony, and that metaphony that appears in one place as a raised vowel may appear elsewhere as a diphthong. Indeed, for reflexes of $*[\varepsilon]$ in some varieties of Ladin (Kramer 1977:63) one finds a situation which looks intriguingly like the 'mirror image' of Castilian: here we have the diphthong before palatals (and also velars) and in historically metaphonizing environments (but also generally in open syllables), but a monophthong [e] elsewhere. While definitive proof remains elusive, it seems to me that a perfectly plausible scenario for Castilian involves initially diphthongizing metaphony of low mid vowels (subsequently generalized to all low mid vowels), which later, in environments where the assimilatory effect of metaphony continued to operate, became subject to closure.$^{57}$ The coexistence of diphthongs and of raised outcomes from original low mid vowels in Castilian does not necessarily preclude a common metaphonic origin for both. 7.2 Romanian evidence for metaphonic raising, not diphthongization, of low mid vowels? For Romanian, Loporcaro (2011b:128-30) discerns evidence of original metaphonic alternation between low (input) vowels and high mid (output) vowels. This is revealed

\footnotetext{
${ }^{56}$ Sánchez Miret (1998:223, 225) explains these facts by postulating original glides preceding the consonants, which allegedly lengthened the stressed vowel (whence the diphthongization). But since in Occitan we have diphthongization in these cases, but not in open syllables, this obliges us to make the rather implausible assumption that vowels in these closed syllables are longer than vowels in open syllables. This would, at the very least, need some empirical confirmation.

${ }^{57}$ See also Barbato (2012). Schürr (1970b:115) sees a diphthongal origin for these monophthongs, but claims that Castilian general diphthongization of low mid vowels arose by contact with dialects in which the diphthongs had not monophthongized.
} 
through a later kind of diphthongization, specific to Romanian involving spontaneous opening of the stressed mid vowels to $e a$ ([ea]) and oa ([oa]), a process blocked where a potentially metaphonizing unstressed vowel was historically present. One result is morphophonological alternation in inflexional paradigms, for example $\operatorname{des}(u)$ 'thick' (< DENSUM) and $\operatorname{porc}(u)$ 'pig' (< PORCUM):

Table 11: Opening diphthongs in Romanian

\begin{tabular}{lllll}
\hline & SG & PL & SG & PL \\
\hline M & des & deşi & porc & porci \\
& & & & \\
\hline $\mathrm{F}$ & deasă & dese (older dease) & poarcă & poarce \\
\hline
\end{tabular}

Loporcaro's concludes that the failure of [ea]/[oa]-diphthongization in environments which (originally) would have had metaphonizing final vowels [u] and [i] must mean that, at the time of the opening diphthongization, there was a distinction between closed (historically, metaphonized) mid vowels and open (historically non-metaphonized) mid vowels, and that only the latter were input to the process of opening diphthongization. If, as Loporcaro argues, the effect of metaphony was raising not diphthongization, and given that the diphthong was itself subject to the effects of opening (e.g., M fiert 'boiled' vs. F fiartă; 3SGPRS.IND pierde 'loses' vs. subjunctive piardă), it follows that [je] must be prior to, hence unconnected with, metaphony. This analysis is possible, but (as so often with questions of early Romanian historical phonology) it is hard to exclude plausible alternatives, one of which is that the $*[e]-[\varepsilon], *[o]-[0]$ alternation, rather than being a matter of metaphonic assimilation, is actually the result of a general, unconditioned, 
process of opening of mid vowels which was blocked before final high vowels (for other examples from Romanian of following unstressed vowels blocking stressed vowel changes, see for example Rothe 1957:18f.). Such an approach would also obviate the problem of explaining why words containing etymological, proto-Romance, $*[\mathrm{e}]$ (rather than $*[\varepsilon])$, with a stressed vowel historically identical to the supposed output of metaphony, were themselves subject to opening diphthongization (e.g., MSG *'negru FSG *'negra > negru neagră 'black').

I cannot, in the end, demonstrate that the opening diphthongs are of metaphonic origin everywhere in Romance, but the scenario whereby the diphthong was originally metaphonic, and became generalized outside its original environment, is perfectly possible across the Romance languages.

\section{THE “MYTH” OF TUSCAN METAPHONY?}

That 'Tuscan lacks metaphony' is received wisdom in manuals of Italo-Romance linguistics and dialectology (e.g., Devoto and Giacomelli 1972:66; Dardano 1991:112; Grassi, Sobrero, and Telmon 1997:98). It is obviously true today in the sense that there are no morphological alternations attributable to it, but historically it is an anomaly. Tuscany, like any region, certainly shows distinctive local phonological innovations (cf., e.g., Maiden 1995:41f.;44), but the alleged absence of metaphony is a different, negative, kind of distinctiveness, involving a curious failure to undergo a process otherwise shared by all the Italo-Romance varieties flanking Tuscany for hundreds of kilometres in either direction. Tuscan is not at the 'periphery of metaphony', an outlying region perhaps untouched by a innovation affecting more central varieties, but a peculiar 'hole in the 
middle' in its geographical distribution. In the foregoing we have seen that this anomaly may be merely apparent, given evidence for the historical presence of metaphony in Tuscany, too. It needs to be added that that the absence of metaphony of high mid vowels in Tuscany does not invalidate the claim that Tuscany had it for low vowels, for there are plenty of attestations from central Italy (including, of course, Arezzo) of metaphony limited, or partially limited, to low mid vowels (cf. Maiden 1987:40;63-66 for an account).

A different scenario might be that the medieval and modern Tuscan distribution of the diphthongs was, so to speak, 'imported ready-made' into Tuscany, having emerged elsewhere (presumably in the north). The possibility that Tuscany might show merely the imported lexical effects of metaphony and of the subsequent spread of the metaphonic diphthong, rather than ever having been home to the processes which led to those effects, was behind my reservations in Maiden (1988:27f.) over the indigenous nature of metaphony in Tuscany. This caution was probably excessive, and there is reason to suppose that metaphonic assimilation, and the subsequent spread of the diphthongs, were also on home soil in Tuscany. For example, importation of the lexical effects of metaphony alone would lead one to predict the absence of the diphthongs from Tuscan toponyms, but the diphthongs are in fact abundantly attested in medieval and modern place names (see, for example, Russo and Sánchez Miret 2009:185f.), such as Siena, Liene, Lieta, Liete, Cuori, Quosa - the last-named attested as early as the eighth century). In general, what one would expect to see, if one were dealing with 'borrowing' from without, is that 'core' vocabulary (e.g., piedi 'feet', puoi 'you can') would resist diphthongization regardless of the identity of the final vowel - but this is not the case. In 
addition, while both northern Italo-Romance and Tuscan show correlation between lack of diphthongization and lack of a historically metaphonizing environment, there is a crucial difference in that one can discern, in the north, a sensitivity to the distinction between final mid vowels and final [a] (see Table 8), whereas I detect no such sensitivity in Tuscany.

For all of the reasons I develop here, I contend that it is not merely possible, but likely, that metaphony operated, historically, in Tuscany as it did practically everywhere else in mainland Italy, and that the modern diphthongs in open syllables are remnants of it. The notion that metaphony underlies Tuscan diphthongization is very far from being a "myth".

\section{CONCLUSION}

In this study I have reviewed in some detail the modern and historical distribution of the effects of opening diphthongization of low mid vowels in Tuscan dialects, and some recent arguments against the idea that they originated in metaphony. I have tried consistently to view the facts in their wider contexts, both phonological and dialectological. Phonologically, the details of the emergence of the diphthongs should not be considered in isolation: deviant as the diphthongs may be in terms of a process which generally yields raising, the circumstances of diphthongization emerge as otherwise closely congruent with those of metaphony. Dialectologically, there is no reason a priori to regard Tuscan as an intrinsically special or autonomous Italo-Romance dialect, although some scholars (notably Castellani) seem to me to have been excessively inclined to do so. Tuscan should be viewed against the wider background of Italo-Romance 
diphthongization of low mid vowels, and in this perspective the facts sit most comfortably and naturally with the notion that Tuscany, like the surrounding territories, did participate in the earliest kind of metaphony of low mid vowels, restricted to open syllables.

As in vast areas of northern Italy (and beyond), an originally metaphonic diphthong seems later to have spread outside its original conditioning environment. In the north, at least, this extension may initially have had a phonological motivation, but it is clear, especially from observation of Tuscan, that paradigmatic morphological information (speakers' knowledge of the presence vs absence of a metaphonic diphthong somewhere in the inflexional paradigm of a lexeme) also came to play a central role in promoting, or impeding, the diphthong's subsequent lexical diffusion.

\section{REFERENCES}

Aebischer, PAul, 1965. 'A propos de foris et foras dans le latin médiéval d'Italie. Considérations sur la répartition de ces deux types dans la Romania', in Omagiu lui Alexandru Rosetti la 70 de ani, Bucharest: Editura Academiei Republicii Socialiste România, 1-10.

AIS = JABERG, KARL \& JUD, JAKOB, 1928-40. Sprach- und Sachatlas Italiens und der Südschweiz, Zofingen: Ringier.

ALEIC = BotTIGLIONI, GINO, 1933-42. Atlante linguistico etnografico italiano della Corsica, Pisa: Italia dialettale.

ALI = Bartoli, Matteo, Pellis, Ugo, \& Massobrio, Lorenzo, (eds) 1995-. Atlante linguistico italiano, Rome: Istituto poligrafico e Zecca dello Stato. 
$A L T=$ Atlante lessicale toscano serverdbt.ilc.cnr.it/altweb

AsColi, GRAZIADIO IsaiA, 1873. 'Saggi ladini', Archivio glottologico italiano 1, 249$316 ; 391-447$.

BADÍA MARGaRit, ANTONIO, 1951. Gramática histórica catalana, Barcelona: Noguer.

BARbato, MARCELlo, 2006. 'Un'ipotesi sul vocalismo corso', L'Italia dialettale 66-67, $7-27$.

BARbato, Marcello, 2012. 'La inflexión revisitada o elogio de la comparación', Revista de Historia de la Lengua Española 7, 71-90.

Barbato, Marcello, 2013. 'La métaphonie romane occidentale', Revue de linguistique romane $77,321-341$.

BARgetTo-ANDRÈs, TERESA, 1998. 'The asymmetrical role of metaphony in Italian dialects', Italian Culture 16, 69-81.

BiAnCHI, BiAnCO, 1886. Il dialetto e la etnografia di Città di Castello. Città di Castello: Lapi.

Camastral, Peter, 1959. 'Il vocalismo dei dialetti della Valle Mesolcina', L'Italia dialettale 23, 75-191.

CAmilli, Amerindo, 1929. 'Il dialetto di Servigliano', Archivum Romanicum 13, 220271.

Carosella, Maria, 1997. 'Metafonesi e differenziazione vocalica sillabica (dvs) nei dialetti garganici nord-occidentali: presentazione dei dati e prime osservazioni', Linguistica italiana meridionale 5, 149-164.

Carosella, Maria, 1999. 'La metafonesi nei dialetti garganici nord-occidentali', Quaderni del dipartimento di linguistica - Università di Firenze 9, 97-138. 
CAROSElla, Maria, 2005. Sistemi vocalici tonici nell'area garganica settentrionale fra tensioni diatopiche e dinamiche variazionali, Rome: Edizioni Nuova Cultura.

Castellani, Arrigo, 1970. 'Ancora sul dittongamento italiano e romanzo. Seconda risposta a Friedrich Schürr', $C N$ 30, 117-130.

Castellani, ArRigo, 1980a [1962]. 'La diphtongaison des $e$ et $o$ ouverts en italien'. Saggi di linguistica e filologia italiana e romanza (1946 - 1976), I, Rome: Salerno, 123138.

CASTELlANI, ARRIGO, 1980b [1962]. 'Quelques remarques à propos de la diphtongaison toscane', Saggi di linguistica e filologia italiana e romanza (1946 - 1976), I, Rome: Salerno, pp. 139-145.

CASTEllani, ARrigo, 1980c [1967]. 'Dittongamento senese e dittongamento aretino nei dialetti dell'Italia meridionale', Saggi di linguistica e filologia italiana e romanza (1946 1976), I, Rome: Salerno, 358-422.

Castellani, ArRigo, 1980d [1970]. 'Note sul dittongamento toscano'. Saggi di linguistica e filologia italiana e romanza (1946 - 1976), I, Rome: Salerno, 146-155.

Castellani, Arrigo, 1980e [1970]. 'Ancora sul dittongamento italiano e romanzo. Seconda risposta a Friedrich Schürr', Saggi di linguistica e filologia italiana e romanza (1946 - 1976), I, Rome: Salerno, 156-176.

Castellani, Arrigo, 1980f [1967]. 'Italiano e fiorentino argenteo', Saggi di linguistica e filologia italiana e romanza (1946 - 1976), I, Rome: Salerno, 17-35.

Castellani, ArRigo, 1980g [1961 and 1964]. 'Note sul Miliadusso'. Saggi di linguistica e filologia italiana e romanza (1946 - 1976), II, Rome: Salerno, 321-387. 
Castellani, Arrigo, 1980h [1972]. 'Frammenti d'un libro di conti castellano del Dugento. Date estreme; 1241-1272; inizio: 1261' Saggi di linguistica e filologia italiana e romanza (1946 - 1976), II, Rome: Salerno, 455-513.

CAStellani, ArRigo, 2000. Grammatica storica della lingua italiana, I, Introduzione, Bologna: Il Mulino.

Cella, RobertA, 2003. I gallicismi nei testi dell'italiano antico, Florence: Accademiea della Crusca.

CLIPS = Corpora e lessici dell'italiano parlato e scritto: http://www.clips.unina.it/it/

D’ACHILle, PaOlo, 2001. Breve grammatica storica dell'italiano, Rome: Carocci.

D’Imperio, Mariapaola and Rosenthall, Sam 1999. 'Phonetics and phonology of main stress in Italian', Phonology 16: 1-28.

DAlBera-STEFAnAgGi, MARIE-José, 1991. Unité et diversité des parlers corses. Le plan phonologique. Parenté génétique et affinité, Alessandria: dell'Orso.

DARDANO, MAURIZIO, 1991. Manualetto di linguistica italiana, Bologna: Zanichelli.

De Angelis, Alessandro, 2014. 'Dittongazione condizionata e dittongazione libera nel dialetto di Tortorici (ME)', in Del Puente, Patrizia (ed.), Dialetti: per parlare e parlarne. Atti del Terzo Convegno Internazionale di Dialettologia, Potenza: Il Segno, 35-58.

De Angelis, M., 1921. Saggio di studio glottologico sulla parlata di Torremaggiore (Foggia), Torremaggiore: Caputo.

Devoto, Giacomo \& Giacomelli, Gabriella, 1972. I dialetti delle regioni d'Italia, Florence: Sansoni. 
EgERLAND, VERNER, 2010. 'On Old Italian uomo and the classification of indefinite expressions', in D'Alessandro, Roberta, Ledgeway, Adam \& Roberts, Ian (eds.) Syntactic Variation. The Dialects of Italy, Cambridge: CUP, 71-85.

EICHENHOFER, WOLFGANG, 1999. Historische Lautlehre des Bündnerromanischen, Tübingen: Francke.

FalCone, GiusePPe 1976. Calabria, Pisa: Pacini.

FANCIULlO, FrANCO, 2014. 'I vocalismi (tonici) romanzi: siamo davvero così sicuri di quello che è successo? Un caso “transizionale"', L'Italia dialettale 75, 81-101.

FOUCHÉ, PIERRE, 1925. 'La diphtongaison en catalan'. Butlletí de dialectologia catalana $13,1-46$.

FrANCESCHI, TeMISTOCLE, 1979. 'La Vallesina nel contesto dei dialetti marchigiani', in Anselmi, S. (ed.). Nelle Marche centrali, Jesi: Cassa di Risparmio di Jesi, 1899-946.

FREUND, ILSE 1933. Beiträge zur Mundart von Ischia, Tübingen: dissertation.

GARCÍA ARIAS, Xosé LluIS, 2003. Gramática histórica de la lengua asturiana, Oviedo: Academia de Llingua Asturiana.

Giammarco, ERnesto, 1979. Abruzzo, Pisa: Pacini.

GIANNINI, ARRIGO, 1939. 'Notizie sulla fonetica del dialetto di Castelnuovo (media valle del Serchio)', L'Italia dialettale 15:53-82.

Gibellini, Pietro, 1991. Giuseppe Gioachino Belli. Sonetti, Rome: Garzanti.

Grassi, Conrado, Sobrero, Alberto, \& Telmon, Tullio, 1997. Fondamenti di dialettologia italiana, Rome: Laterza.

GRIMALDI, MiRKo, 2003. Nuove ricerche sul vocalismo tonico del Salento meridionale, Alessandria: dell'Orso. 
Gysling, FriTZ, 1929. 'Contributo alla conoscenza del dialetto della Valle Anzasca', Archivum Romanicum 13, 87-190.

HAJEK, John and StEVEns, MARY 2008. 'Vowel duration, compression and lengthening in stressed syllables in central and southern varieties of standard Italian'. In Interspeech 2008. Bonn: ISCA, 516-519.

HeILmann, Luigi, 1955. La parlata di Moena nei suoi rapporti con Fiemme e con Fassa: saggio fonetico e fonematico, Bologna: Zanichelli.

Kramer, Johannes, 1977. Historische Grammatik des Dolomitenladinischen. Lautlehre, Würzburg: Wissenschaftlicher Verlag Lehmann.

LAUSBERG, HeINRICH, 1965. Lingüística románica I, Madrid: Gredos.

LEI = PFISTER, MAX and SCHWEICKARD, WOLFGANG (1979- ). Lessico etimologico italiano. Wiesbaden: Reichert.

LEONARD, ClifFORD, 1978. Umlaut in Romance: an essay in linguistic archaeology, Grossen-Linden: Hoffmann.

LindSSTRÖM, A., 1907. 'Il vernacolo di Subiaco', Studj romanzi 5, 237-300.

Loporcaro, Michele, 1988. Grammatica storica del dialetto di Altamura, Pisa: Giardini.

LOPORCARO, Michele, 2011a. 'Syllable, segment and prosody', in Maiden, Martin, Martin, Smith, John Charles, \& Ledgeway, Adam (eds). The Cambridge History of the Romance Languages, Cambridge: Cambridge University Press, 50-108.

LoporCARo, Michele, 2011b. 'Phonological processes', in Maiden, Martin, Martin, Smith, John Charles, \& Ledgeway, Adam (eds) The Cambridge History of the Romance Languages, Cambridge: Cambridge University Press, 109-154. 
LÜDTKE, Helmut, 1956. Die strukturelle Entwicklung des romanischen Vokalismus, Bonn: Romanisches Seminar an der Universität Bonn.

Maccarrone, Nunzio, 1915. Il dialetto di Cassino e di Cervaro, Perugia: Unione Tipografica Cooperativa.

MAIDEN, MARTIN, 1985. “'Displaced" metaphony and the morphologization of metaphony', Romance Philology 39, 22-34.

MAIDEN, MARTIN, 1986. Metaphony and the Italian Dialects: a study in morphologisation. University of Cambridge: $\mathrm{PhD}$. thesis.

MAIDEN, MARTIN, 1987. 'New perspectives on the genesis of Italian metaphony', Transactions of the Philological Society, 38-73

MAIDEN, MARTIN, 1988. 'On the dynamics of diphthongization in Tuscan and GalloItalian', Canadian Journal of Italian Studies 11, 1-37.

MAIDEN, MARTIN, 1989. 'Sulla morfologizzazione della metafonesi nei dialetti italiani meridionali', Zeitschrift für romanische Philologie 105, 178-192

MAIDEN, MARTIN, 1991. Interactive Morphonology. Metaphony in Italy, London: Routledge.

MAIDEN, MARTIN, 1995. A Linguistic History of Italian, London: Longman.

MAIDEn, MARTin, 1996. 'On the Romance inflectional endings $-i$ and $-e$ ', Romance Philology 50, 147-182.

MaIden, MARTin 1998. Storia linguistica dell'italiano, Bologna: Il Mulino.

MAIDEN, MARTIN, 2007. 'On the morphology of Italo-Romance imperatives', in Bentley, Delia \& Ledgeway, Adam (eds), Sui dialetti italoromanzi. Saggi in onore di Nigel B. Vincent, Norfolk: Biddles, 148-164. 
Mancarella, Giovan Battista, 1964. Il dialetto di Gubbio nel Trecento. Manduria:

La Tipografica Manduriana.

Mancarella, Giovan Battista, 1970. ‘Arcaicità del sistema vocalico salentino', Studi linguistici salentini 3, 111-126.

Mancarella, Giovan Battista, 1998. Salento. Monografia regionale della carta dei dialetti italiani, Lecce: del Grifo.

Manni, PaOla, 1979. 'Ricerche sui tratti fonetici e morfologici del fiorentino quattrocentesco', Studi di grammatica italiana 8, 115-171.

Medori, STELla, 2013. 'Eléments gallo-italiens et gallo-romans dans les parlers corses', Revue de linguistique romane 77, 121-138.

Melillo, Michele, 1955. Atlante fonetico pugliese: Capitanata e terra di Bari. Rome: Marcello.

Melillo, Giacomo, 1926. I dialetti del Gargano (Saggio fonetico), Pisa: Simoncini. Merlo, Clemente, 1920. Fonologia del dialetto di Sora, Pisa: Forni.

Milano, Emma, 2002. 'La dinamica dei fenomeni di palatalizzazione della $a$ tonica in una comunità dell'Area Flegrea', Bollettino linguistico campano 1, 197-236.

Millardet, GeORges, 1910. Etude de dialectologie landaise. Toulouse: Privat. MOLL, FRANCESC DE BORJA, 1952. Gramática histórica catalana. Madrid: Gredos. Navarro Tomás, Tomás, 1916. 'Cantidad de las vocales acentuadas', Revista de filología española 3, 387-408.

OVI = Opera del Vocabolario Italiano http:www.ovi.cnr.it

Pellegrini, Giovan Battista, 1982. 'Osservazioni di sociolinguistica italiana', L'Italia dialettale 45, 1-36. 
Penny, RalPH 2002. A History of the Spanish Language. Cambridge: Cambridge University Press.

Pollidori Castellani, Ornella, 1961. 'Lieva - leva', Studi linguistici italiani 2, 167f.

PurCZINSKY, JUliUS, 1970. 'A Neo-Schuchardtian theory of general Romance diphthongization', Romance Philology 23, 492-528.

REINHARD, TONI, 1956. 'Umbrische Studien', Zeitschrift für romanische Philologie 72, 153.

RiBezzo, F., 1912. 'Il dialetto apulo-salentino di Francavilla Fontana' . Martina Franca.

ROHLFS, GERHARD 1938. 'Der Einfluß des Satzakzentes auf den Lautwandel', Archiv für das Studium der neueren Sprachen 174, 54-56.

ROHLFS, GERHARD, 1941. 'Galloitalienische Sprachkolonien am Golf von Policastro (Lukanien)', Zeitschrift für romanische Philologie 61, 79-113.

ROHLFS, GERHARD, 1966. Grammatica storica della lingua italiana e dei suoi dialetti. Fonetica, Turin: Einaudi.

ROHLFS, GERHARD, 1968. Grammatica storica della lingua italiana e dei suoi dialetti. Morfologia, Turin: Einaudi.

ROHLFS, GERHARD, 1969. Grammatica storica della lingua italiana e dei suoi dialetti. Sintassi e formazione delle parole, Turin: Einaudi.

Rothe, Wolfgang, 1957. Einführung in die historische Laut- und Formenlehre des Rumänischen, Halle: Niemeyer.

Russo, Michela \& SÁnchez Miret, Fernando, 2009. 'La diphtongaison romane et la métaphonie. Le paradoxe du faible au fort', Recherches linguistiques de Vincennes 38, 161-206. 
SAlviOnI, CARLO, 1886. 'Saggio intorno ai dialetti di alcune vallate all'estremità settentrionale del lago Maggiore', Archivio glottologico italiano 9, 188-260.

SÁNCHEZ MiRet, FERnANDO, 1998. La diptongación en las lenguas románicas, Munich: Lincom.

Savoia, Leonardo \& Maiden, Martin, 1997. 'Metaphony', in Maiden, Martin and Parry, Mair (eds), The Dialects of Italy, London: Routledge, 15-25.

SCHUCHARDT, HugO, 1885. Ueber die Lautgesetze. Gegen die Junggrammatiker. Berlin: Oppenheim.

SCHÜRR, FRIEDRICH, 1965. 'Grundsätzliches zu den Fragen der romanischen, insbesondere italienischen Diphtongierung', Archiv für das Studium der neuren Sprachen 201, 321-339.

SCHÜRR, FRIEDRICH, 1970a. 'Dittongazione e quantità sillabica fenomeni distintivi tra i dialetti umbri e quelli contermini', in I dialetti dell'Italia mediana con particolare riguardo alla regione umbra. Atti del V convegno di Studi Umbri (Gubbio, 28 maggio - 1 giugno 1967). Gubbio: Centro di Studi Umbri presso la Casa di Sant'Ubaldo / Perugia: Facoltà di Lettere e Filosofia, 381-401.

SCHÜRR, FRIEDRICH, 1970b. La Diphtongaison romane, Tübingen: Narr.

SCHÜRR, FRIEDRICH, 1972. 'Epilogo alla discussione sulla dittongazione romanza', Revue de linguistique romane 36, 311-321.

SCHÜRR, FRIEDRICH, 1980. La dittongazione romanza, Ravenna. Girasole.

SERIANNI, LUCA, 1972. 'Ricerche sul dialetto aretino nei secoli XIII e XIV', Studi di filologia italiana 30, 59-191. 
SERIANNI, LuCA, 1999a [Review of Maiden 1998], Studi di linguistica italiana 25, 108116.

SERIANNI, LUCA, 1999b. Lezioni di grammatica storica italiana, Rome: Bulzoni.

Sestito, Francesco, 2004. 'Aspetti linguistici di un documento inedito dell'assisano quattrocentesco: lo statuto di Radicofani (1441)', Studi linguistici italiani 30, 161-203.

SGANZINI, SiLvio, 1928. 'Osservazioni sul vocalismo dei dialetti della Valle di Blenio', L'ltalia dialettale 4, 150-167.

SILVESTRI, GIUSEPPINA, 2009. 'La metafonia nel dialetto di Verbicaro (CS)', L'Italia dialettale 70, 169-226.

SPOERRI, TheOPHIL, 1918. 'Il dialetto della Valsesia', Rendiconti del reale Istituto lombardo di scienze e lettere II, 51, 391-409; 683-98; 732-52.

SPORE, PALlE, 1972. La Diphtongaison romane, Odense: University of Odense Press.

Stehl, Thomas, 1980. Die Mundarten Apuliens: Historische und strukturelle Beiträge, Münster, Aschendorff.

ToppINo, G., 1905. 'Il dialetto di Castellinaldo', Archivio glottologico italiano 16, 517548.

Textes de Français Ancien: http://artfl-project.uchicago.edu/content/tfa VAN COETSEM, Frans and BuCCINI, ANTHONY (1990). 'Variation and the reconditioning of phonological rules. Cases from Germanic and Romance', Lingua 81:169-220. VAN DER VeER, BART (2001). 'Eppur si muove: un'analisi critica dell'uso del dittongo mobile nel Novecento'. Studi di grammatica italiana 20:139-253. 
VANELLI, LAURA, 2010. 'Verbi con allomorfia e allotropia tematica nel tema di presente', in Salvi, Giampaolo \& Renzi, Lorenzo (eds), Grammatica dell'italiano antico, Bologna: Il Mulino, 1463-1468.

Ventigenovi, Aldo, 1993. 'Il monottongamento di uo a Firenze', Studi linguistici italiani 19, 170-212.

VignOLI, CARLO, 1925. I1 vernacolo di Veroli, Rome: Società filologica romana.

WARtBurg, WALther vON, 1950. Die Ausgliederung der romanischen Sprachräume, Bern: Francke.

WeInRICH, Harald, 1958. Phonologische Studien zur romanischen Sprachgeschichte, Münster: Äschendorffsche Buchhandlung.

ZAmboni, Alberto, 1993. 'Sulla tipologia del vocalismo cisalpino: implicazioni diacroniche e classificatorie', in Hilty, Gerold (ed.), Actes du XXe Congrès International de Linguistique et Philologie Romanes, III/IV, Tübingen: Francke, 463-471.

ZICCARDI, G., 1910. 'Il dialetto di Agnone. La fonetica e la flessione', Zeitschrift für romanische Philologie 34, 405-436. 